NBER WORKING PAPER SERIES

WILL THE DOHA ROUND LEAD TO PREFERENCE EROSION?

\author{
Mary Amiti \\ John Romalis \\ Working Paper 12971 \\ http://www.nber.org/papers/w12971 \\ NATIONAL BUREAU OF ECONOMIC RESEARCH \\ 1050 Massachusetts Avenue \\ Cambridge, MA 02138 \\ March 2007
}

This paper was written when both authors were at the IMF Research Department. We thank Kalpana Khochar, Raghu Rajan, Arvind Subramanian, and Shang-Jin Wei for helpful comments. The views expressed herein are those of the author(s) and do not necessarily reflect the views of the National Bureau of Economic Research.

(C) 2007 by Mary Amiti and John Romalis. All rights reserved. Short sections of text, not to exceed two paragraphs, may be quoted without explicit permission provided that full credit, including $\odot$ notice, is given to the source. 
Will the Doha Round Lead to Preference Erosion?

Mary Amiti and John Romalis

NBER Working Paper No. 12971

March 2007

JEL No. F13,F14,F17

\begin{abstract}
$\underline{\text { ABSTRACT }}$
This paper assesses the effects of reducing tariffs under the Doha Round on market access for developing countries. It shows that for many developing countries, actual preferential access is less generous than it appears because of low product coverage or complex rules of origin. Thus lowering tariffs under the multilateral system is likely to lead to a net increase in market access for many developing countries, with gains in market access offsetting losses from preference erosion. Furthermore, comparing various tariff-cutting proposals, the research shows that the largest gains in market access are generated by higher tariff cuts in agriculture.
\end{abstract}

\author{
Mary Amiti \\ International Research \\ Federal Reserve Bank of New York \\ 33 Liberty St \\ New York, NY 10045-0001 \\ Mary.Amiti@ny.frb.org \\ John Romalis \\ University of Chicago \\ Graduate School of Business \\ 5807 South Woodlawn Avenue, Ste. 421 \\ Chicago, IL 60637 \\ and NBER \\ jromalis@gsb.uchicago.edu
}




\title{
Will the Doha Round Lead to Preference Erosion?
}

\author{
Mary Amiti and John Romalis*
}

This paper assesses the effects of reducing tariffs under the Doha Round on market access for developing countries. It shows that for many developing countries, actual preferential access is less generous than it appears because of low product coverage or complex rules of origin. Thus lowering tariffs under the multilateral system is likely to lead to a net increase in market access for many developing countries, with gains in market access offsetting losses from preference erosion. Furthermore, comparing various tariff-cutting proposals, the research shows that the largest gains in market access are generated by higher tariff cuts in agriculture.

A key issue in the Doha Round, especially for developing countries, is whether multilateral tariff reductions will adversely affect their market access to developed countries. ${ }^{1}$ In large part, this concern stems from the fact that developing countries were given nonreciprocal preferential access to developed countries' markets in the 1970s. These preferences entitle developing countries to export their products to developed countries at lower tariff rates than those applied to other World Trade Organization (WTO) members and, in some cases, at zero tariff rates. If tariff cuts were to be granted to all WTO members under the Doha Round, then the relative advantage of developing countries' exports to developed countries would be reduced due to the erosion of these "preference margins" - the difference between the tariff rate for all WTO members and their own under their preferential access. However, offsetting these losses of preference erosion are the gains in market access due to tariff cuts on goods that do not receive preferences. The question is whether the gains outweigh the losses.

Using detailed trade, tariff, and preference information for the United States and the European Union, this paper assesses the likely effects of reducing tariffs under the Doha Round on market access for developing countries. A key feature of this is study is the use of data on preference schemes, with details of which preference schemes different products were exported to the U.S. and EU markets. This information is essential in assessing the size of preference erosion as many tariff lines are not eligible for preferences under the Generalized System of Preferences (GSP), and in many cases countries do not apply for preferences they are entitled to and end up paying the MFN rate because of complex rules governing the use of preferences. Thus studies that assume 100 percent utilization rates are likely to over-estimate the costs of preference erosion.

We estimate changes in market access by simulating changes in the United States and the European Union's import demand following cuts in their bound tariff rates under three

* This paper was written when both authors were at the IMF Research Department. Mary Amiti is a Senior Economist at the Federal Reserve Bank of New York, and John Romalis is an Associate Professor at the University of Chicago. We thank Kalpana Khochar, Raghu Rajan, Arvind Subramanian, Shang-Jin Wei, and an anonymous referee for helpful comments.

${ }^{1}$ Other issues, such as loss in tariff revenue, are not addressed in this paper. 
different policy scenarios. ${ }^{2}$ First, we assume that they cut all their tariffs by a uniform rate of 40 percent. Second, we allow the United States and the European Union to exclude sensitive products from tariff cuts. Third, we assume a higher than 40 percent tariff cut in agriculture, and a 40 percent tariff cut in manufacturing. These different scenarios are meant to reflect likely outcomes that have been discussed in the Doha negotiations.

To simulate changes in import demand requires some assumptions about demand and supply elasticities. We assume the elasticity of substitution across different varieties of products is equal to 6 , as in Romalis (forthcoming). ${ }^{3}$ Throughout the analysis, the supply elasticity for developing countries is assumed to be infinite. This enables the focus to be on the change in demand from the European Union and the United States for developing countries' products as a way to measure changes in market access. If, instead, a finite elasticity were assumed then trade volume responses would be smaller but there would be terms of trade effects from which some developing countries would benefit. The infinite elasticity of supply assumption delivers the maximum export revenue effect, both for revenue gains and losses, but is unlikely to cause a misidentification of winners and losers. ${ }^{4}$

The results highlight that preferences granted to developing countries are not as generous as they appear. Some developing countries actually pay higher average tariffs than developed countries under current preference schemes. For example, the average tariffs imposed by the United States on non-African least developed countries' (LDCs') exports is 13.1 percent compared with only 1.2 percent imposed on developed countries' exports. Similarly in the European Union, the average tariff on non-African LDCs is higher, at 5.1 percent, than on developed country exports, at 2.9 percent.

Because a large share of developing countries' exports do not actually enjoy preferences in practice, lowering tariffs under the multilateral system is likely to lead to a net increase in market access. That is, the gains in market access from lower MFN tariffs offset the losses due to preference erosion for many developing countries. A simulated uniform cut in tariffs of 40 percent in both the United States and the European Union leads to an increase in import demand of 2.1 percent averaged across all countries, although the gains are not uniform across countries or regions. Non-African LDCs enjoy higher than average increases in demand for their products, of 8.5 percent, and African LDCs experience a loss of 0.1 percent in demand for their products. If the United States and the European Union were to exclude sensitive products from tariff cuts, the gains in market access for all regional groupings would be smaller, on average, relative to the uniform cut. Simulations that assume

${ }^{2}$ A bound tariff is the maximum tariff that a country can set, as agreed under WTO negotiations. The Most-Favored-Nation (MFN) tariff is the tariff rate applied to all WTO member countries that do not receive special preferences.

${ }^{3}$ Simulations with alternative elasticity of substitution assumptions are also presented to show robustness of the results.

${ }^{4}$ This infinite supply elasticity assumption differs from that made in Subramanian (2003) and Alexandraki and Lankes (2004) where a supply elasticity of one is assumed and no terms of trade effects are considered. Their assumptions deliberately bias the results in favor of overstating losses from preference erosion in order to minimize the risk of overlooking individual countries that might face losses. In addition, they also assume $100 \%$ utilization of preferences. 
a higher than 40 percent tariff cut in agriculture, using a tiered formula, together with a 40 percent cut in manufacturing, generate the largest gains for all groups of countries.

\section{Research Strategy}

To estimate changes in market access, we simulate changes in import demand by the United States and the European Union following across-the-board tariff reductions. We assume a Cobb-Douglas utility function in the first tier at the product level, which implies an elasticity of substitution between goods equal to one. Thus, the total share of expenditure on each product at the HS 10-digit level, for example shoes, is assumed to be constant. Within this shoe product group, each country will decide from where to purchase different varieties, where each country is assumed to produce a different variety. The elasticity of substitution across these different varieties is assumed to equal 6 , thus if the relative price of shoes in one country increases by one percent, relative demand for its shoes will fall by 6 percent. These assumptions are based on estimates from Romalis (forthcoming) and are consistent with other studies, such as Hummels (2001). Simulations with alternative elasticity of substitution assumptions are also presented to show robustness of the results. Each country's current share of EU and U.S. consumption is estimated from the detailed trade data and from the OECD's STAN database. The full details of the estimation procedure are provided in Appendix I. ${ }^{5}$

We assume that the supply elasticity for developing countries is infinite. This enables us to focus on the change in demand from the European Union and the United States for developing countries' products as a way to measure changes in market access. ${ }^{6}$ Implicitly, this implies that all exporting countries will readily respond to the shifts in U.S. and EU demand stemming from tariff changes under the Doha Round. Of course this is unlikely to be the case, notably due to supply-side constraints, such as impediments in infrastructure. Thus, some countries may not necessarily be able to take advantage of increase in demand for their products if there are infrastructure problems limiting export capacities. However, without detailed country information on supply constraints by commodity it would be impossible to incorporate these aspects. To determine how much trade in various commodities will change would require information on supply capacity and other factors that affect supply, which are outside the scope of this exercise. Nevertheless, an advantage of the infinite supply elasticity assumption is that the simulations provide an indication of changes in potential market access. Since one of the concerns surrounding the next Doha Round is loss in market access due to preferences erosion, this seems the most appropriate assumption to make. If, instead, a finite elasticity were assumed, then trade volume responses would be smaller but there would be terms of trade effects from which some developing countries would benefit. The infinite

\footnotetext{
${ }^{5}$ Note that these numbers are likely to understate the potential gains in market access and the number of gaining countries since only the 'intensive margin' of trade is modeled i.e. if there were no exports of a particular good from a particular country to the United States or European Union before the tariff cut, there will also be no exports to those countries following the cut. This is particularly relevant for high-tariff goods where tariff cuts could lead to changes in the 'extensive margin' that are not captured in these simulations.

${ }^{6}$ Romalis (2005) finds high supply elasticities, but these estimates were not confined to developing countries. The effects of other proposals in the Doha Round such as cuts in export subsidies on agricultural products are not considered here. The focus is on changes in market access resulting from tariff cuts.
} 
elasticity of supply assumption delivers the maximum export revenue effect, both for revenue gains and losses, but is unlikely to cause a misidentification of winners and losers. ${ }^{7}$

The relative change in a country's competitiveness due to tariff cuts is explicitly modeled. When there are across-the-board tariff cuts, developing countries face two main effects. First, where developing country goods currently enter tariff-free, a reduction in bound tariffs must worsen the competitive position of those developing country exports because tariff reductions reduce the average tariff their competitors face in the U.S. and EU markets. Thus the demand for these developing countries' exports falls. Second, where developing country goods enter U.S. and EU markets at the MFN rate, whether due to the absence of a preference or an inability to utilize a preference, a reduction in MFN tariffs improves the competitive position of those developing countries' exports because it reduces the tariff imposed on goods where they have a comparative cost advantage. Their position also improves relative to U.S. and EU domestic producers and relative to exporters to the United States and European Union that benefit from preferential trade agreements. The relative demand for developing country exports of these goods increases. The net effect depends on whether the losses in preference erosion from the first effect outweigh the gains from tariff cuts due to the second effect.

\section{DAta}

The study utilizes trade data under various preference schemes. The GSP is a set of trade preferences granted on a non-reciprocal basis by developed countries to developing countries. The system was negotiated over the 1964-1971 period with the first major scheme implemented by the EEC in July 1971, with Japan following suit in August 1971 and the United States in January 1976 (Baldwin and Murray, 1977). All GSP schemes involve tariff concessions to a range of developing country exports. Under the current U.S. scheme, for example, out of a total of 15,467 articles listed in U.S. tariff lines, most developing countries may export 6,409 articles duty-free, where imports of the same article from most developed countries would attract a positive tariff (Ozden and Reinhardt, 2002). All countries that receive preferences from the United States or the European Union or both are labeled LDC or developing in Table 10 of Appendix II. ${ }^{8}$ Note that there are many preferences in place other than the GSP, which are listed in Table 11 of Appendix II. Prominent examples include EU preferences for African, Caribbean and Pacific (ACP) countries and U.S. preferences for African countries under the African Growth and Opportunity Act (AGOA).

\footnotetext{
${ }^{7}$ Papers that assume finite supply elasticities also find small losses from preference erosion. In simulations following a 40 percent cut in MFN rates, Subramanian (2003) finds that losses from preference erosion for LDCs as a whole are very small and likely to be less than 2 percent of exports, and only two countries face losses greater than 10 percent of exports. Alexandraki and Lankes (2004) extend this analysis to middle-income developing countries and also find the overall impact to be small, between 0.5 and 1.2 percent of total exports, but it could be much higher for a subset of countries that are overwhelmingly export-dependent on a few products, namely sugar, bananas, and to a lesser extent, textiles. Note, that there could also be further gains due to productivity improvements due to lower tariffs on inputs. See Amiti and Konings (20005).

${ }^{8}$ The countries marked with an asterisk do not receive preferences from the U.S. All EU members are labeled 'Developed'.
} 
It is important to utilize actual preference scheme data as many tariff lines are not eligible for preferences under the GSP, and in many cases countries do not apply for preferences they are entitled to and end up paying the MFN rate because of complex rules governing the use of preferences. Product coverage, defined as the ratio of imports that were eligible to enter under the GSP to total imports, was only 44 percent for LDC beneficiaries of the United States' GSP scheme (dutiable imports in 2002 were $\$ 6.7$ billion, of which $\$ 2.9$ billion were covered by the GSP scheme). ${ }^{9}$ Within this low product coverage, preference utilization rates, defined as the ratio of imports that received preferences to total imports eligible for preferences, by LDC exporters to the United States are high, at 95.8 percent for the GSP (out of the \$2.9 billion of imports eligible for GSP \$2.8 billion received preferential treatment). (See UNCTAD, 2003.) ${ }^{10}$ In the European Union, although product coverage is almost 100 percent, preference utilization rates are low. For LDC exporters to the European Union, preference utilization rates are on average 76 percent for ACP countries and 57 percent on average for non-ACP countries (UNCTAD, 2003). Sometimes preferences are not utilized because there are other more beneficial preference schemes that developing countries can apply for. The preference utilization rates for AGOA were over 80 percent in 2002, however there were sixteen countries that utilized less than 50 percent of the available AGOA preferences. (See Brenton and Ikezuki, 2004). ${ }^{11}$

Preferences that are due to be phased in over the next few years are assumed to have already taken place. This avoids counting gains and losses to LDCs that will come from the European Union's phased elimination of tariffs for sugar, rice, and bananas under its Everything But Arms Program (EBA), the enhancement of the European Union's GSP scheme for LDCs, and the phased elimination of EU tariffs on sugar, rice, and banana imports from ACP countries. It is assumed that LDCs already have tariff-free access to the European Union for those exports. These tariffs will be reduced or eliminated regardless of how the Doha Round turns out. Since the focus of this paper is whether a multilateral tariff reduction resulting from a successful Doha Round itself would lead to preference erosion, these earlier commitments are taken as given.

\footnotetext{
${ }^{9}$ Product coverage is much lower when mineral products are excluded (HS Chapters 25-27, mostly oil), collapsing to 3.9 percent ( $\$ 1.5$ billion out of $\$ 3.9$ billion of dutiable imports).

${ }^{10}$ Previous studies have also identified limitations of GSP. For example, not all developing countries are included (Baldwin and Murray, 1977). Programs typically exclude products where developing countries have the greatest comparative advantage (Devault, 1996). Export eligibility ceilings are often binding (Macphee and Rosenbaum, 1989). The programs impose strict rules of origin requirements (UNCTAD, 2001) and do not remove non-tariff barriers. Up to 42 countries have temporarily dropped or have been permanently 'graduated' by the U.S. at some time since 1976 (Ozden and Reinhardt, 2003). The U.S. has allowed the GSP to lapse on occasions, including one period in excess of a year, increasing uncertainty for exporters. Mattoo, Roy and Subramanian (2002) highlight that the stringent rule-of-origin that requires exporters to source certain inputs from within Africa or the United States severely restricts the potential benefits from the preferences granted under AGOA.

${ }^{11}$ Brenton and Ikezuki (2004) also point out that products that are excluded from AGOA preferences are high-duty products; and the U.S. is not a major export destination for many AGOA country exports. These low utilization rates are likely due to high compliance costs such as paperwork and red tape. Francois, Hoekman and Manchin (2005) find a threshold preference margin of 4 percent below which preference margins are irrelevant because of these costs.
} 
The tariff cuts in the policy experiments are applied to the bound rates, rather than directly on MFN rates, as will be the case in the Doha Round. If a tariff is not currently bound it is assumed to be bound at the current MFN rate, and tariff cuts are then applied. ${ }^{12}$ If the new bound rate falls below the MFN rate then the MFN rate is also reduced. ${ }^{13}$ All tariff rates are at the most detailed product line available, which includes more than 10,000 different products - this is at the HS 10-digit level for the United States and HS 8-digit level for the European Union. ${ }^{14}$

The study focuses on the effects of tariff cuts by the United States and the European Union. ${ }^{15}$ Although this does not capture the total effects of trade liberalization under the Doha Round, it does incorporate a sizeable share. ${ }^{16}$ The shares of LDCs' and other developing countries' exports to the United States and the European Union markets combined are approximately 50 percent, as seen in Table 1. Individual country export shares to the European Union and United States are provided in Table 10, Appendix II.

Table 1. Export Shares, 2003

\begin{tabular}{lccccc}
\hline & $\begin{array}{c}\text { Total Exports } \\
\text { (U.S.\$ billions) }\end{array}$ & $\begin{array}{c}\text { Share to U.S. } \\
\text { (percent) }\end{array}$ & $\begin{array}{c}\text { Share to EU-15 } \\
\text { (percent) }\end{array}$ & $\begin{array}{c}\text { Share to Other } \\
\text { Developed } \\
\text { Countries } \\
\text { (percent) }\end{array}$ & $\begin{array}{c}\text { Share to } \\
\text { Developing } \\
\text { Countries } \\
\text { (percent) }\end{array}$ \\
\hline $\begin{array}{l}\text { African } \\
\begin{array}{l}\text { LDCs } \\
\text { Non-African }\end{array}\end{array}$ & 26.5 & 24.70 & 29.92 & 11.26 & 34.12 \\
$\begin{array}{l}\text { LDCs } \\
\text { Other } \\
\text { developing } \\
\text { countries } \\
\begin{array}{l}\text { Developed } \\
\text { countries }\end{array}\end{array}$ & 16.6 & 25.14 & 24.82 & 12.25 & 37.79 \\
\hline Source: & $1,870.0$ & 23.34 & 20.20 & & \\
\hline
\end{tabular}

Source: World Integrated Trade Solution (WITS), World Bank.

\footnotetext{
${ }^{12}$ Note that over 99 percent of U.S. and EU tariffs are bound (WTO, 2002).

13 The EU's preferential tariffs for developing countries are reduced using the formulas in European Commission (2003a).

14 Approximately 10 percent of tariff lines include specific tariffs, which have been converted to ad valorem equivalent tariffs by UNCTAD in the case of EU tariffs and by dividing actual duty paid by the value of imports in the case of the United States.

${ }^{15}$ The most recent available data for the United States is 2004 and for European Union it is 2003.

16 Thus these results understate the gains from the Doha Round because the simulations do not take account of tariff cuts by other countries. Yang (2005) points out that African countries can increase their gains by also seeking greater market access in developing countries as well as making their own liberalization commitments.
} 


\section{RESULTS}

\section{Current State of Play}

There are many limitations to GSP programs that result in inferior access to developed markets for some developing countries. First, despite preferences given to LDCs and developing countries, the average tariffs paid are sometimes higher on developing country exports. This is due to different commodity composition and different preference schemes. Table 2 shows that products that are exported by non-African LDCs face higher tariffs (13.1 percent) than products exported to the United States by other developing countries (1.8 percent), which are in turn higher than tariffs on products exported by developed countries (1.1 percent). The African LDCs enjoy the lowest average tariffs into the U.S. market at 0.1 percent. For each product, defined at the U.S. tariff-line level, the average tariff is calculated as the value of collected duties divided by the value of imports. Similarly, in the European Union, ${ }^{17}$ non-African LDCs face the highest average tariffs but these are much lower at 5.1 percent than those paid in the United States. This difference arises because LDCs enjoy lower tariffs due to the European Union's EBA program and due to the European Union's program for ACP countries.

Table 2. Average Tariffs Are Higher on Non-African LDCs' Goods Exported to the United States and European Union

\begin{tabular}{lcc}
\hline Exporter & Average Tariff Paid on U.S. Imports & $\begin{array}{c}\text { Average Tariff Paid on EU } \\
\text { Imports }\end{array}$ \\
\hline African LDCs & 0.07 & 0.80 \\
& $(0.60)$ & $(7.67)$ \\
Non-African LDCs & 13.14 & 5.10 \\
& $(8.46)$ & $(4.57)$ \\
Other developing countries & 1.82 & 2.37 \\
& $(4.61)$ & $(10.21)$ \\
Developed countries & 1.15 & 2.89 \\
& $(2.96)$ & $(6.29)$ \\
\hline
\end{tabular}

Source: WITS, U.S. Census Bureau and European Union. Tariffs are averaged across all goods. The standard deviation of tariffs is reported in parentheses.

Second, on average, higher tariffs are paid on goods exported to the United States where LDCs and developing countries have comparative advantage than on goods that

${ }^{17}$ Note that total duties collected were unavailable for the European Union. The estimated tariff paid on a product exported by a particular country is a weighted average of the EU MFN tariff for that product and the lowest tariff that product may be eligible for under various EU preference arrangements. The weight on the lowest tariff is the preference utilization rate for exports of that product from that country. Detailed preference utilization rates were obtained from the European Union. Estimated average tariffs for a group of products and/or exporting countries are trade-weighted averages of the estimated tariffs for each product and exporting country. 
developed countries enjoy comparative advantage. ${ }^{18}$ Despite preferences, products in which LDCs and other developing countries enjoy a comparative advantage are still highly taxed in the United States. Table 3 shows average tariffs paid on each region's comparative advantage goods on world exports to the United States and European Union. It shows that average tariffs on LDCs' comparative advantage goods exported to the United States are higher than average tariffs paid on developed countries' comparative advantage goods (3.8 for nonAfrican LDCs and 1.8 percent for African LDCs compared with only 1 percent for developed countries). However, this is not the case on goods exported to the European Union. The average tariff paid on African LDCs' comparative advantage goods exported to the EU market is on average lower (at 1.1 percent) than on non-African comparative advantage goods (at 2.3 percent). Other developing country comparative advantage goods exported to the European Union attracted the highest average tariff of 2.9 percent.

Table 3. Average Tariffs Are Higher on LDC and Developing Country Comparative Advantage Goods in the United States

\begin{tabular}{lcc}
\hline Comparative Advantage & $\begin{array}{c}\text { Average Tariff Paid on U.S. Imports } \\
\text { on Each Country's Comparative } \\
\text { Advantage Products }\left(\mathrm{B}_{\mathrm{ij}}>1\right)\end{array}$ & $\begin{array}{c}\text { Average Tariff Paid on EU Imports } \\
\text { on Each Country's Comparative } \\
\text { Advantage Products }\left(\mathrm{B}_{\mathrm{ij}}>1\right)\end{array}$ \\
\hline African LDCs & 1.79 & 1.09 \\
Non-African LDCs & 3.82 & 2.34 \\
Other developing countries & 2.64 & 2.90 \\
Developed countries & 0.97 & 2.78 \\
\hline
\end{tabular}

Source: WITS, U.S. Census Bureau, and European Union. The average tariff reported for each region's comparative advantage goods is the trade-weighted-average tariff paid on all U.S. or EU imports of those goods from all countries.

Third, in goods where LDCs have comparative advantage, the average tariff paid by non-African LDCs is higher than other regional groupings. Table 4 presents average tariffs by country grouping for goods where the LDCs (both African and non-African) have comparative advantage, indicated by a Balassa index greater than one. Non-African LDCs, on average, pay higher average tariffs on these products in the United States and European Union. In contrast, African LDCs enjoy the lowest tariffs on their comparative advantage goods in both the U.S. and EU markets. These differences can be explained by the different preference schemes. Non-African LDCs pay higher than average tariffs on their comparative advantage goods in the U.S. market mainly because the GSP in the United States applies to less than 50 percent of imports. ${ }^{19}$ Conversely, African LDCs pay lower tariffs because they

${ }^{18}$ For each region, comparative advantage in each good is identified using the Balassa index of revealed comparative advantage, defined as $\mathrm{B}_{\mathrm{ij}}=\frac{\mathrm{x}_{\mathrm{ij}} / \mathrm{X}_{\mathrm{j}}}{\mathrm{x}_{\mathrm{i}} / \mathrm{X}}$ where $\mathrm{x}_{\mathrm{ij}}$ is industry $i$ exports in region $j$, $\mathrm{x}_{\mathrm{j}}$ is total exports by region $j, \mathrm{x}_{\mathrm{i}}$ is total industry $i$ exports in the world and $\mathrm{X}$ is total exports in the world. A number greater than one indicates revealed comparative advantage in that industry. Note that a country's comparative advantage is endogenous, and these are presented only for the purposes of illustrating why developing countries might be receiving inferior market access.

19 See Dean and Wainio (2005) for detailed measures of size, utilization, and value of U.S. nonreciprocal trade preferences. 
enjoy special preferences such as AGOA and because their exports comprise a higher proportion of lower-taxed minerals.

Table 4. Non-African LDC Countries Enjoy No Special Access for Their Comparative Advantage Goods Relative to Developed Countries

\begin{tabular}{|c|c|c|}
\hline Exporter & $\begin{array}{c}\text { Average Tariff Paid on U.S. } \\
\text { Imports on LDCs Comparative } \\
\left.\text { Advantage Products (LDC } B_{i j}>1\right)\end{array}$ & $\begin{array}{c}\text { Average Tariff Paid on EU Imports } \\
\text { on LDCs Comparative Advantage } \\
\left.\text { Products (LDC } B_{i j}>1\right)\end{array}$ \\
\hline African LDCs & 0.06 & 0.94 \\
\hline Non-African LDCs & 13.53 & 5.35 \\
\hline Other developing countries & 3.96 & 2.35 \\
\hline Developed countries & 2.80 & 1.56 \\
\hline
\end{tabular}

Source: WITS, U.S. Census Bureau, and European Union. The average tariff reported for LDC comparative advantage goods is the trade-weighted-average tariff paid on U.S. or EU imports of LDC comparative advantage goods from each of the four exporting regions.

\section{Effects of U.S. and EU Tariff Reductions on All Goods}

We conduct three policy experiments to assess the change in import demand arising from tariff cuts: (i) A uniform tariff reduction of 40 percent on bound rates; ${ }^{20}$ (ii) Exclusion of Special Products. Countries will negotiate on the number of tariff lines that will be allowed to be excluded from tariff cuts, and they will be able to choose which tariff lines to exclude. Since it is unclear which product lines will be chosen, an exclusion list of 3 percent of the highest tariff lines is assumed for this simulation; and (iii) A tiered formula for agriculture. The current proposal is for 5 bands for developed countries, with different tariff cuts to be applied to different levels of tariffs. Because the actual details have yet to be negotiated, the simulations here are based on the Harbinson proposal (WTO, 2003), with a 40 percent cut in tariffs under 20 percent, 50 percent cut in tariffs between 20 percent and 80 percent, and 60 percent cut for tariffs above 80 percent, with a 100 percent cap. ${ }^{21}$ No tariff lines are excluded in this simulation.

The results show that gains in market access to the United States and European Union under a successful conclusion of the Doha Round are likely to more than offset any losses due to preference erosion for many LDCs and other developing countries. ${ }^{22}$ Table 5 shows that on average, all country groupings, except African LDCs, enjoy an increase in combined market access to the United States and European Union following a 40 percent cut in tariffs. African LDCs experience a small loss of 0.1 of a percent on average. Non-African LDCs enjoy the largest percentage increase in access to the combined U.S. and EU markets under

\footnotetext{
${ }^{20}$ It is impossible to know exactly what the tariff cut will be under the next Doha Round. This number is based on cuts in previous rounds and pre-Doha Round informal discussions.

${ }^{21}$ Sebastian, Laborde and Martin (2005) also base their numbers on the Harbinson proposal, with some variations, arguing that although the proposal was not adopted its transition points are likely to reflect a great deal of consultations and thought.

${ }^{22}$ These results are consistent with Francois, Hoekman and Manchin (2005) that shows the potential magnitude of preference erosion is reduced due to the high compliance costs of obtaining preferences. In their policy experiment all OECD members abolish all trade distorting policies.
} 
all policy scenarios presented. The gains in market access for all country groupings are reduced if exclusion of the highest tariff lines is allowed. The largest gains for all countries occur with a tiered formula in agriculture (which results in an average tariff reduction of 50 percent in the case of EU tariffs and 47 percent in the case of U.S. tariffs).

Table 5. Improved Market Access for Developing Countries Under Doha Round Assuming 40 Percent Uniform Tariff Cut by Region

\begin{tabular}{|c|c|c|c|c|c|c|c|c|c|}
\hline \multirow{3}{*}{ Exporter } & \multicolumn{3}{|c|}{ No Exclusions } & \multicolumn{3}{|c|}{$\begin{array}{c}\text { Exclusion of Highest } 3 \\
\text { Percent Tariff Lines }\end{array}$} & \multicolumn{3}{|c|}{$\begin{array}{l}\text { Tiered Formula in } \\
\text { Agriculture }\end{array}$} \\
\hline & \multicolumn{9}{|c|}{ Change in Import demand by: } \\
\hline & EU & U.S. & $\begin{array}{l}\text { EU\&U.S. } \\
\text { Combined }\end{array}$ & EU & U.S. & $\begin{array}{l}\text { EU\&U.S. } \\
\text { Combined }\end{array}$ & EU & U.S. & $\begin{array}{l}\text { EU\&U.S. } \\
\text { Combined }\end{array}$ \\
\hline African & & & & & & & & & \\
\hline $\begin{array}{l}\text { LDCs } \\
\text { Non-African }\end{array}$ & 0.64 & -1.01 & -0.15 & 0.17 & -0.75 & -0.27 & 0.83 & -1.01 & -0.04 \\
\hline $\begin{array}{l}\text { LDCs } \\
\text { Other }\end{array}$ & 4.14 & 13.90 & 8.54 & 4.08 & 10.64 & 7.04 & 4.16 & 13.90 & 8.55 \\
\hline $\begin{array}{l}\text { developing } \\
\text { countries } \\
\text { Developed }\end{array}$ & 2.84 & 1.86 & 2.28 & 2.12 & 1.63 & 1.83 & 3.19 & 1.88 & 2.43 \\
\hline countries & 2.97 & 1.59 & 1.98 & 2.41 & 1.47 & 1.72 & 3.27 & 1.60 & 2.08 \\
\hline All & 2.89 & 1.73 & 2.14 & 2.26 & 1.55 & 1.79 & 3.21 & 1.74 & 2.27 \\
\hline
\end{tabular}

Source: authors' calculations. The tiered formula is based on the Harbinson proposal - 40 percent cut in tariffs under 20 percent, 50 percent cut in tariffs between 20 percent, 80 percent, and 60 percent for tariffs above 80 percent with a 100 percent cap.

A closer examination within the LDC regional group in Table 6 and within the developing country group in Table 7 reveals that some countries experience net losses in market access under all policy experiments. For example, Haiti experiences large losses due to losses in clothing exports. (See also Table 12, Appendix II, for individual country results.) Sub-Saharan African countries experience a loss in the U.S. market due to losses in mineral exports, mainly crude petroleum. ${ }^{23}$ Some countries experience net gains under all policy experiments, with non-African LDC gains driven by South Asian and other LDC countries, which experience large gains in clothing exports. Within the developing country grouping, presented in Table 7, Mexico experiences net losses mainly because of its free trade agreement with the United States; further tariff cuts by the United States for other countries will reduce its relative advantage. China and South Asian countries gain from further tariff cuts because they derive relatively little benefit from existing preferences.

${ }^{23}$ U.S. tariffs on petroleum are 5.25 cents per barrel for light crude oil, 10.5 cents per barrel for heavier grades of crude oil, and 52.5 cents per barrel for more refined products such as gasoline. Preferences (zero tariffs) are given to most developing countries (but not to most OPEC members) and to partners of free trade agreements. So the preference is small, but since oil is by far the biggest export from African LDCs to the United States, it plays a large part in the simulation results. But it is unlikely that African LDCs would suffer falls in aggregate petroleum exports in the short term. What is more likely to happen is that U.S. tariff reductions for other suppliers causes a redirection of petroleum exports since the direction of commodity trade tends to minimize transport costs plus taxes. 
Table 6. LDCs by Region

\begin{tabular}{|c|c|c|c|c|c|c|c|c|c|}
\hline \multirow{3}{*}{ Exporter } & \multicolumn{3}{|c|}{ No Exclusions } & \multicolumn{3}{|c|}{$\begin{array}{l}\text { Exclusion of Highest } \\
3 \text { Percent Tariff Lines }\end{array}$} & \multicolumn{3}{|c|}{$\begin{array}{c}\text { Tiered formula in } \\
\text { agriculture }\end{array}$} \\
\hline & \multicolumn{9}{|c|}{ Change in Import demand by: } \\
\hline & EU & U.S. & $\begin{array}{l}\text { EU\&U.S. } \\
\text { Combined }\end{array}$ & EU & U.S. & $\begin{array}{l}\text { EU\&U.S. } \\
\text { Combined }\end{array}$ & EU & U.S. & $\begin{array}{l}\text { EU\&U.S. } \\
\text { Combined }\end{array}$ \\
\hline Sub-Saharan & & & & & & & & & \\
\hline Africa & 0.64 & -1.01 & -0.15 & 0.17 & -0.75 & -0.27 & 0.83 & -1.01 & -0.04 \\
\hline South Asia & 3.53 & 14.94 & 7.82 & 3.50 & 10.66 & 6.19 & 3.54 & 14.94 & 7.82 \\
\hline Haiti & 1.63 & -4.87 & -4.61 & 1.63 & -2.99 & -2.81 & 1.64 & -4.87 & -4.61 \\
\hline Other LDCs & 6.32 & 16.66 & 12.13 & 6.15 & 13.86 & 10.48 & 6.38 & 16.66 & 12.16 \\
\hline
\end{tabular}

Source: authors' calculations. The tiered formula is based on the Harbinson proposal -40 percent cut in tariffs under 20 percent, 50 percent cut in tariffs between 20 percent and 80 percent, and 60 percent for tariffs above 80 percent, with a 100 percent cap.

Table 7. Developing Countries by Region

\begin{tabular}{|c|c|c|c|c|c|c|c|c|c|}
\hline \multirow{3}{*}{ Exporter } & \multicolumn{3}{|c|}{ No Exclusions } & \multicolumn{3}{|c|}{$\begin{array}{l}\text { Exclusion of Highest } \\
3 \text { percent Tariff Lines }\end{array}$} & \multicolumn{3}{|c|}{$\begin{array}{l}\text { Tiered Formula in } \\
\text { Agriculture }\end{array}$} \\
\hline & \multicolumn{9}{|c|}{ Change in Import demand by: } \\
\hline & EU & U.S. & $\begin{array}{l}\text { EU\&U.S. } \\
\text { Combined }\end{array}$ & EU & U.S. & $\begin{array}{l}\text { EU\&U.S. } \\
\text { Combined }\end{array}$ & EU & U.S. & $\begin{array}{l}\text { EU\&U.S. } \\
\text { Combined }\end{array}$ \\
\hline Sub-Saharan & & & & & & & & & \\
\hline Africa & 0.99 & -0.28 & 0.43 & 0.84 & -0.21 & 0.38 & 1.12 & -0.28 & 0.51 \\
\hline South Asia & 4.04 & 6.14 & 4.93 & 3.45 & 5.27 & 4.22 & 4.27 & 6.14 & 5.06 \\
\hline Caribbean and & & & & & & & & & \\
\hline Latin America & 5.77 & 1.10 & 2.71 & 2.04 & 0.98 & 1.35 & 7.40 & 1.18 & 3.32 \\
\hline China & 4.00 & 3.42 & 3.62 & 3.94 & 3.13 & 3.42 & 4.06 & 3.42 & 3.65 \\
\hline Mexico & 0.79 & -0.54 & -0.48 & 0.77 & -0.43 & -0.38 & 0.80 & -0.54 & -0.48 \\
\hline $\begin{array}{l}\text { Other } \\
\text { developing }\end{array}$ & & & & & & & & & \\
\hline countries & 1.87 & 2.69 & 2.18 & 1.38 & 2.08 & 1.64 & 2.14 & 2.69 & 2.35 \\
\hline
\end{tabular}

Changing the value of the elasticity of substitution between varieties does not change the overall message. Changes in market access under alternative demand elasticity assumptions are presented in Table 8. A higher demand elasticity results in larger gains in market access. The change in import demand by the European Union and United States increases from 1.1 percent, when the elasticity of substitution is assumed to equal -3.5 , to 4.6 percent when the elasticity of substitution is assumed to be -11 . The effect of changing the elasticity of substitution is to proportionally alter the gains and losses, but in most cases it is the same countries that experience gains or losses. 
Table 8. Change in Market Access with Alternative Demand Elasticity Assumptions Under the Doha Round Assuming 40 percent Uniform Tariff Cut by Region

\begin{tabular}{|c|c|c|c|c|c|c|c|c|c|}
\hline & \multicolumn{9}{|c|}{ No Exclusions } \\
\hline \multirow{3}{*}{$\begin{array}{l}\text { DEMAND } \\
\text { ELASTICITY } \\
\text { Exporter }\end{array}$} & \multicolumn{3}{|c|}{-3.5} & \multicolumn{3}{|c|}{-6.0} & \multicolumn{3}{|c|}{-11} \\
\hline & \multicolumn{9}{|c|}{ Change in Import demand by: } \\
\hline & $\overline{\mathrm{EU}}$ & U.S. & $\begin{array}{l}\text { EU\&U.S. } \\
\text { Combined }\end{array}$ & EU & U.S. & $\begin{array}{l}\text { EU\&U.S. } \\
\text { Combined }\end{array}$ & $\mathrm{EU}$ & U.S. & $\begin{array}{l}\text { EU\&U.S. } \\
\text { Combined }\end{array}$ \\
\hline $\begin{array}{l}\text { African } \\
\text { LDCs } \\
\text { Non-African }\end{array}$ & 0.36 & -0.49 & -0.05 & 0.64 & -1.01 & -0.15 & 2.11 & -2.05 & 0.13 \\
\hline $\begin{array}{l}\text { LDCs } \\
\text { Other }\end{array}$ & 2.03 & 6.85 & 4.12 & 4.14 & 13.90 & 8.54 & 8.63 & 28.31 & 17.49 \\
\hline $\begin{array}{l}\text { developing } \\
\text { countries } \\
\text { Developed }\end{array}$ & 1.36 & 0.90 & 1.10 & 2.84 & 1.86 & 2.28 & 6.10 & 3.91 & 4.83 \\
\hline countries & 1.44 & 0.78 & 1.01 & 2.97 & 1.59 & 1.98 & 6.26 & 3.34 & 4.39 \\
\hline All & 1.39 & 0.84 & 1.06 & 2.89 & 1.73 & 2.14 & 6.15 & 3.64 & 4.62 \\
\hline
\end{tabular}

Source: authors' calculations.

Whether a country loses market access following trade liberalization critically depends on how much of its exports currently benefit from existing preferences. The higher the current preference margin, the higher the loss from preference erosion, and hence the less likely that the gains will outweigh the losses. Figure 1 plots the predicted change in U.S. market access following a 40 percent cut in tariffs with the tiered formula applied to agriculture for each country against the current average "preference margin", defined as the difference between the average tariff rates actually paid on those countries' exports to the United States and the MFN tariff rate applicable to those exports. The exporting country tends to lose market access from general tariff cuts whenever this average preference margin is 5 percent or above. 
Figure 1. Average Preference Margin and Predicted Change in U.S. Market Access

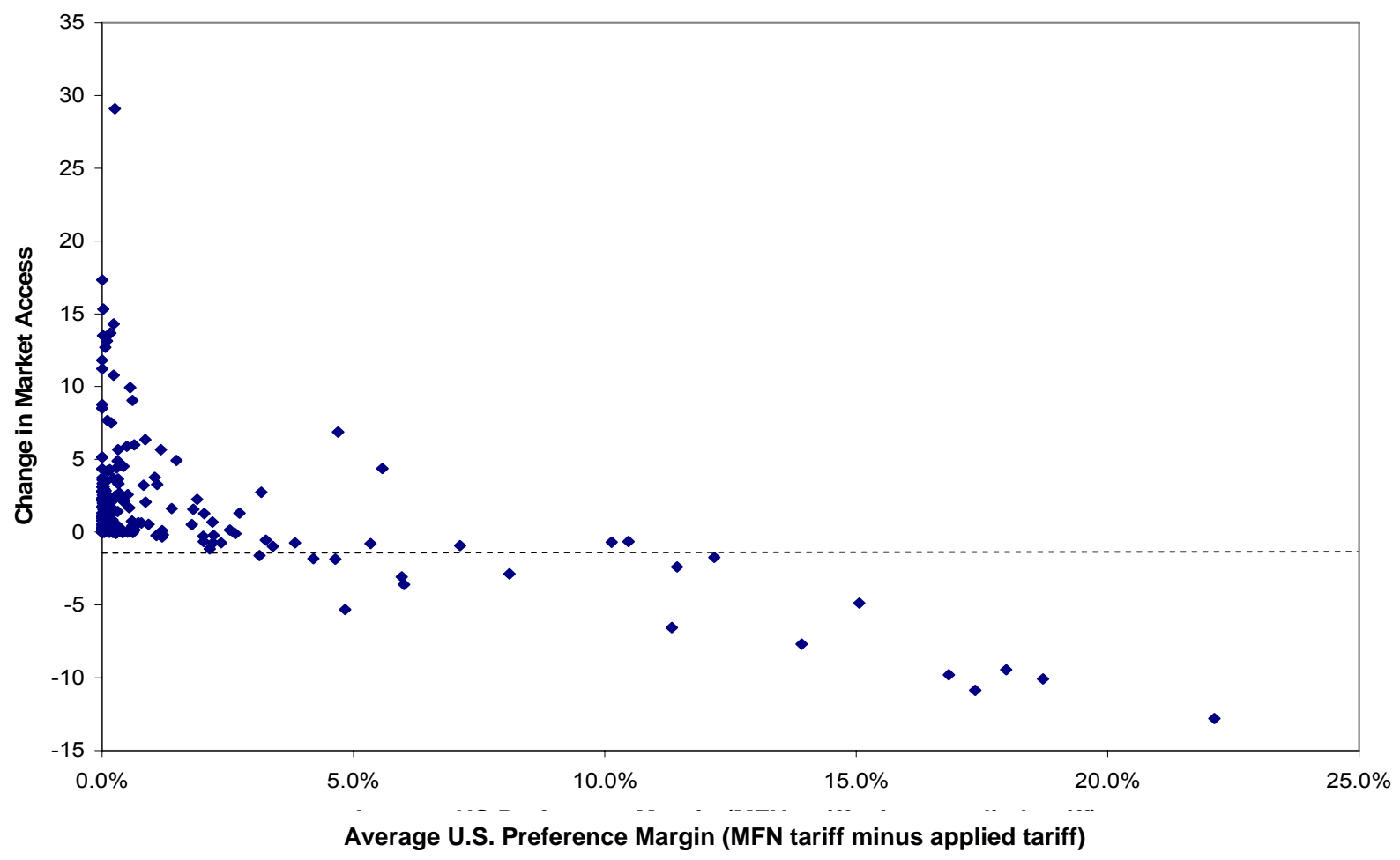

An alternative way to calculate average preference margins is to take account of preferences relative to the domestic U.S. market. This gives an indication of the preferences that developing countries receive relative to all their competitors, which includes U.S. domestic producers. When domestic production is taken into account, it becomes clear that effective preferences are actually quite small and only a small number of countries enjoy positive preference margins. As can be seen from Figure 2, average preferences measures that take account of domestic production imply negative preference margins for many countries. Figure 2 clearly shows that countries with positive preference margins stand to lose market access from across-the-board tariff cuts as a result of preference erosion. In contrast, countries with negative preference margins gain because as tariffs fall the price of U.S. imports relative to domestic production also falls, making developing country exports more competitive. 
Figure 2. Change in Market Access and Average Preference Margin in the United States

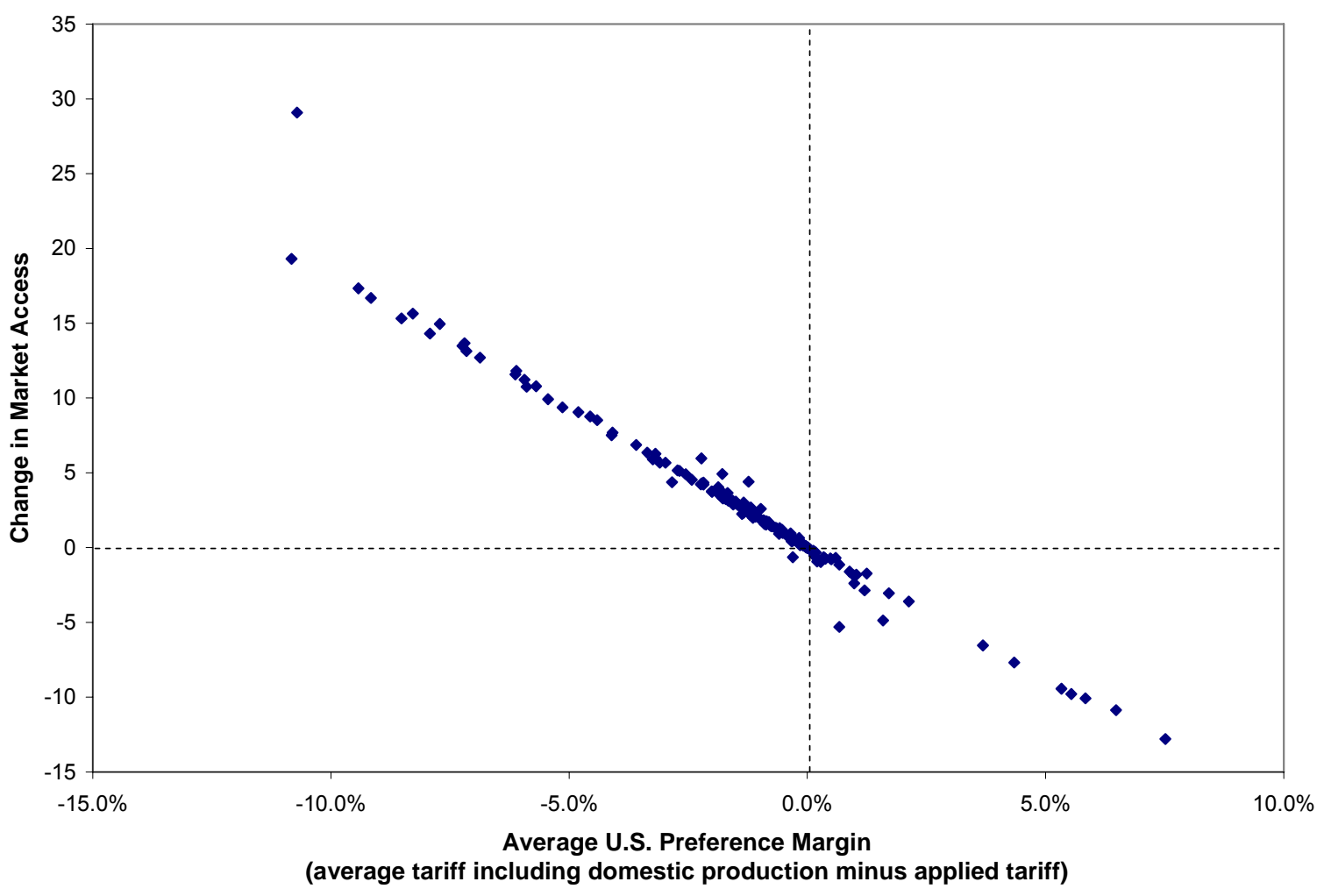

Once changes in access to the EU market are also included, Figure 3 shows some more pronounced market access gains, as well as large projected losses for some countries. Malawi, Zambia, Barbados, Guyana and Swaziland show substantial market access gains in agricultural products such as sugar, tobacco, and rice once the EU market is included, whereas the simulations indicate either no gains or, in some cases, losses in market access to the United States. Gains in one market may offset losses in another. Argentina, Fiji, Mauritius and New Zealand are also projected to win substantial gains in access to EU markets, again driven by agricultural products such as corn, beef, sugar, lamb, fruit, and dairy products. The simulations show that two small countries, Dominica and St Lucia, experience large losses in combined market access to the United States and European Union. Both these countries enjoy exceptionally high preference margins due to preferential arrangements for their banana exports to the European Union. Banana exports from Dominica to the European Union were US\$7.6m in 2003, equal to 37 percent of its total exports to the European Union and 32 percent of its total exports to the EU and U.S. markets - 99 percent of Dominica's banana exports to the European Union enter under preferential arrangements. These banana exports are reduced to US\$2.6 million following tariff cuts of 40 percent in the European Union. Even more extreme is St. Lucia, which exported bananas worth US\$23.7 million dollars to the European Union in 2003, equal to 89 percent of its aggregate exports to the European Union and 58 percent of its combined exports to the European Union and United 
States, with 100 percent of its banana exports to the European Union entering under preferential arrangements. A 40 percent MFN tariff cut reduces its banana exports to the European Union to just $\$ 8.1$ million. In sum, those countries with the highest average preference margins in the United States and the European Union stand to lose the most market access through preference erosion, while those with low or moderate average preference margins are likely to gain market access.

Figure 3. Change in Market Access and Average Preference Margin in the United States and European Union

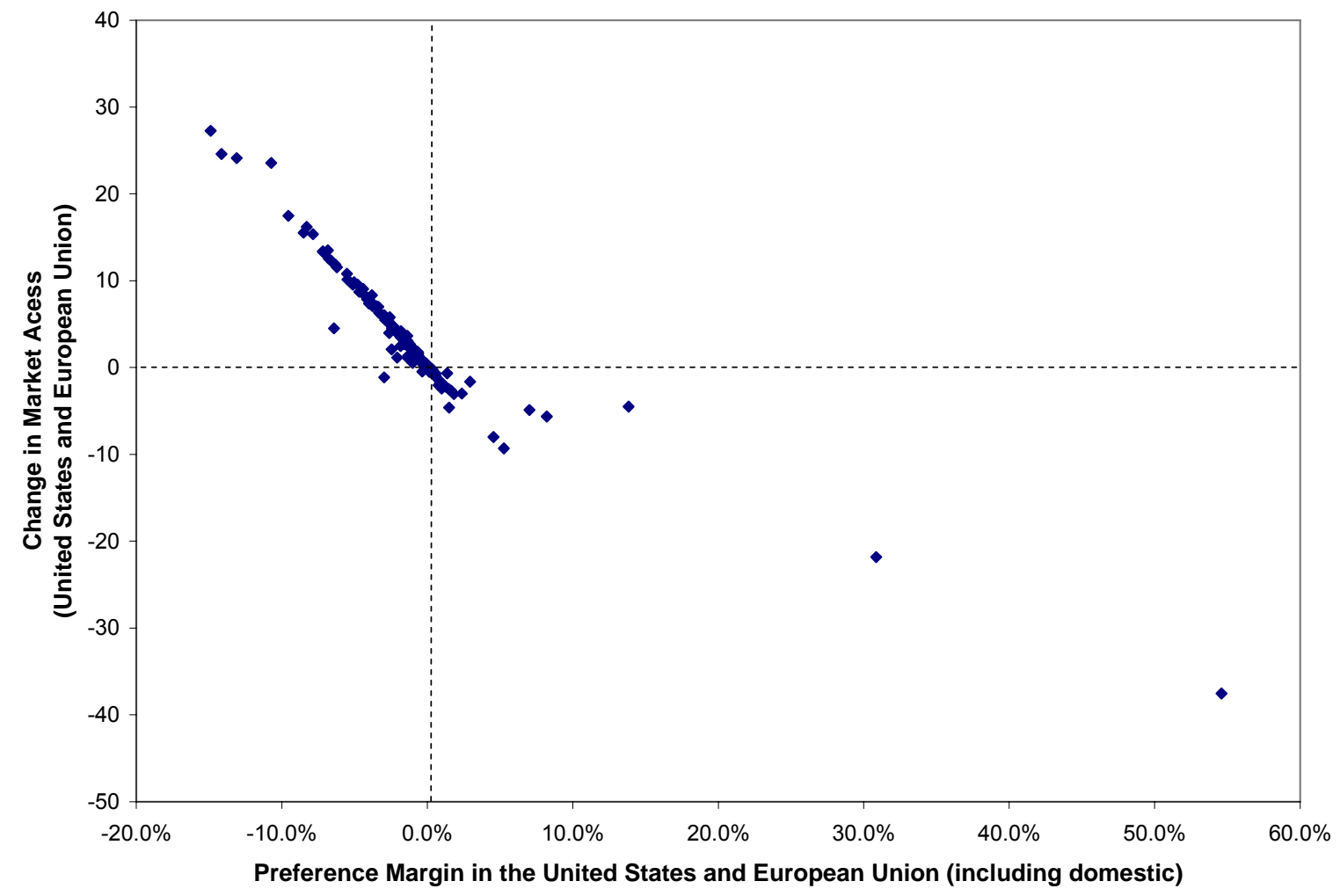

The breakdown of results by product groupings in Table 9 shows that the largest gains are likely to be in agriculture in the EU market and textiles in the U.S. market. The increase in market access to the EU market in agriculture for all countries is 13.05 percent; and the increase in the U.S. market in textiles and clothing is 8.6 percent. However, these gains are not uniformly distributed. African LDCs lose 9.6 percent in market access to the U.S. market in textile and clothing and 1.8 percent in the EU market, yet they experience a gain of 1.8 percent in agriculture in the combined U.S. and EU markets. The smallest gains for all countries are in minerals and other manufacturing categories. Exclusion of the highest 3 percent tariff lines reduces the magnitude of the gains; however, the relative rankings of the product groupings remain unchanged. A tiered formula in agriculture inflates the gains for all country groupings. 
Table 9. Improved Market Access for Developing Countries Under the Doha Round Assuming 40 Percent Uniform Tariff Cut in Agriculture and Textiles

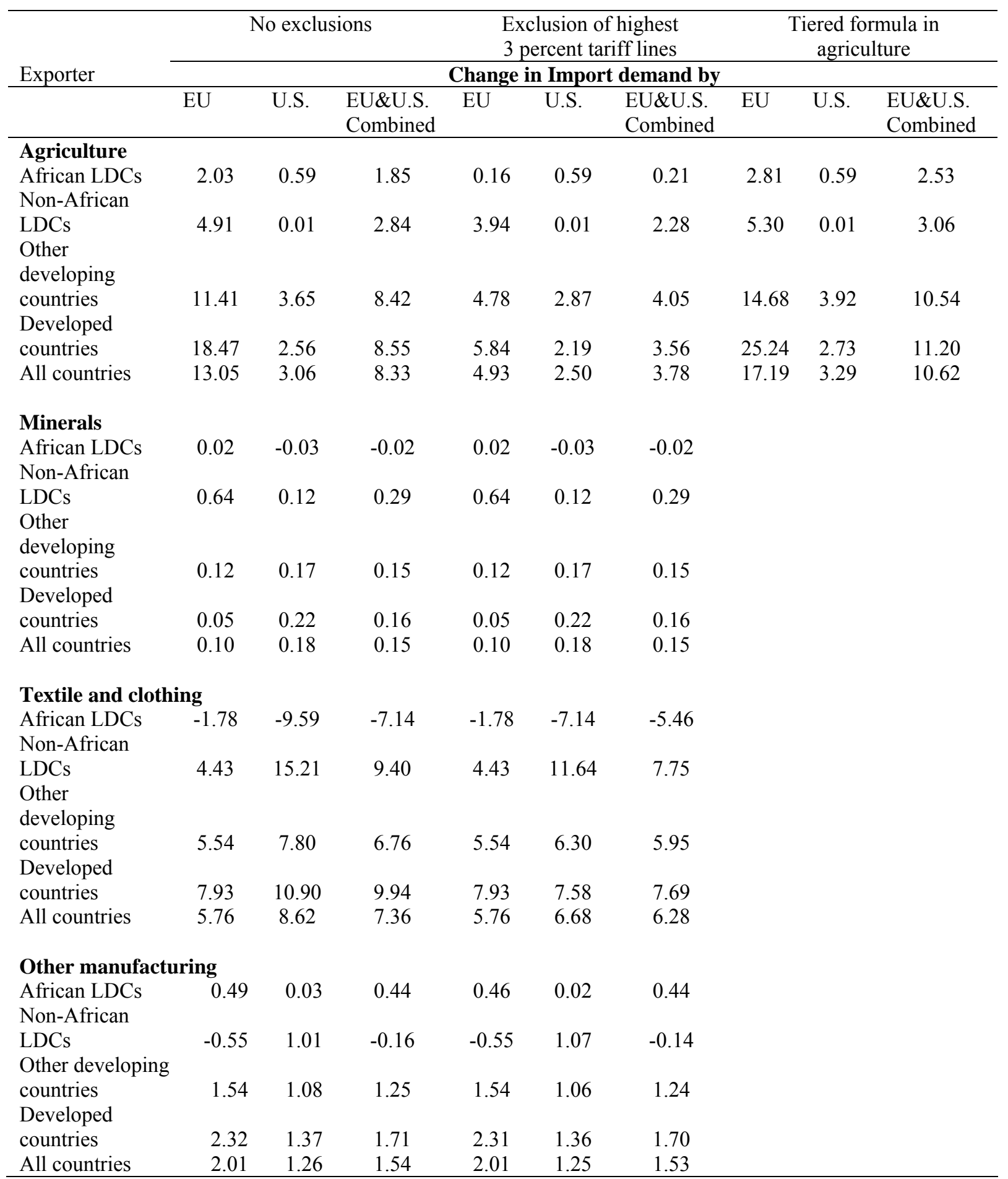

Source: author's calculations. The tiered formula is based on the Harbinson proposal -40 percent cut in tariffs under 20 percent, 50 percent cut in tariffs between 20 percent and 80 percent, and 60 percent for tariffs above 80 percent with a 100 percent cap. 


\section{CONCLUSIONS}

This paper assesses the likely gains in market access for LDCs and developing countries following proposals for tariff cuts under the Doha Round. This was analyzed by simulating changes in import demand by the United States and the European Union, following cuts in the MFN tariff rates of around 40 percent. In contrast to other studies, our model incorporates preference utilization rates rather than assuming that preferences are fully utilized. Since preference utilization rates are as low as 50 percent for some countries, this is an important contribution in order to avoid over-estimating losses from preference erosion. We take into account all available tariff, trade, and utilization information for all products.

The results show that a cut in MFN tariffs by the United States and the European Union leads to improved access to their markets for many developing countries that more than offsets losses due to preference erosion. The small numbers of developing countries that are likely to lose market access as a result of multilateral tariff cuts are the ones that receive very large benefits under existing preference schemes. This result can be explained by noting that currently many developing countries actually have inferior market access to developed countries: average tariffs on non-African LDCs' exports to the United States are higher than those on developed countries (13.1 percent compared with 1.2 percent). Our results also suggest that to maximize these net gains in market access, countries should minimize excluded tariff lines and opt for a tiered formula with higher-than-average tariff cuts in agriculture. 


\section{Appendix I: Technical Information}

The detailed steps involved in calculating the change in market access and average preference margins are as follows.

\section{(1) Change in Market Access}

Step 1: Calculate total U.S. imports for each product $i$ in the base period 0 (year 2003).

Denote total imports in the base period $\mathrm{M}_{0 \mathrm{i}}=\Sigma_{\mathrm{j}} \mathrm{M}_{0 \mathrm{ijp}}$, where $\mathrm{M}_{\mathrm{ijp}}$ is U.S. imports of product $i$ from country $j$ that enters under tariff program $p$. This calculation is performed at the tariffline level (10-digit level).

\section{Step 2: Estimate total U.S. consumption for each product $i$.}

Denote total consumption in the base period $\mathrm{C}_{0 \mathrm{i}}=\mathrm{M}_{0 \mathrm{i}} / \mathrm{m}: \mathrm{c}_{\mathrm{i}}$, where $\mathrm{m}: \mathrm{c}_{\mathrm{i}}$ is the estimated ratio of imports to consumption calculated from the OECD's STAN database of domestic production, imports and exports. The STAN database includes data for approximately 30 primary and secondary industries and is concorded to each tariff line.

\section{Step 3: Calculate the new tariff rates $t_{1 i j p}$ using existing tariff rates $t_{0 i j p}$ as the base rates.}

The new tariff rates will include a 40 percent tariff cut as the benchmark. In the second set of simulations 3 percent of the highest tariff rates will be excluded; and in the third set of simulations a tiered formula will be applied to agriculture with no other exclusions.

\section{Step 4: Estimate new U.S. imports of each product $\boldsymbol{i}$ from each country $\boldsymbol{j}$ under each import program $p$.}

The utility function is assumed to be Cobb-Douglas, which implies an elasticity of substitution of one between different goods at the HS 10-digit level. Hence, a fixed proportion of income is spent on each good.

Within these 10-digit categories, countries produce different varieties. U.S. consumers allocate their demands across products $i$. The import quantity demanded for country $j$ goods under program $p$ is given by maximizing the utility function subject to the budget constraint

$$
q_{0 i j p}=p_{0 i j p}^{1-\sigma}\left(1+t_{0 i j p}\right)^{1-\sigma} P_{i}^{\sigma-1} Y_{0 i}
$$

where $p_{0 i j p}$ is the free-on-board price, $t_{0 i j p}$ is the tariff rate, $P$ is the price index of all substitute varieties and $C_{o i}$ is the expenditure on product $i$ in period 0 . Multiplying both sides by $p$ gives the value of imports in period $0, M_{0 i j p}$. Analogously, the total quantity of imports demanded from each country can be written as follows: 


$$
M_{1 i j p}=M_{0 i j p} *\left(\frac{1+t_{1 i j p}}{1+t_{0 i j p}}\right)^{\sigma-1} *\left(\frac{C_{0 i}}{\sum_{j} \sum_{p} M_{0 i j p} *\left(\frac{1+t_{1 i j p}}{1+t_{0 i j p}}\right)^{\sigma-1}+C_{0 i}-M_{0 i}}\right)
$$

after substituting in for the price index and incorporating price changes from period 0 to period 1 that arise from changes in tariffs. Note that $C_{0 i}-M_{0 i}$ is expenditure on domestically produced goods. The elasticity of substitution between different "varieties", $\sigma$, is assumed to be 6. A "variety" is defined as the interaction of country $j$ product and import program $p$.

\section{Step 5: Calculate the change in "market access."}

The change in market access is defined as the change in U.S. demand for imports from each country as $\Delta \mathrm{MA}_{\mathrm{j}}=100 *\left(\Sigma_{\mathrm{ip}} \mathrm{M}_{1 \mathrm{ijp}} / \Sigma_{\mathrm{ip}} \mathrm{M}_{0 \mathrm{ijp}}-1\right)$.

It is assumed that the export elasticity is infinite, thus the exporting country does not change its export prices exclusive of tariffs.

Step 6: Repeat the process for EU imports, with some modifications. These modifications were necessary because the EU data on preference utilization, though detailed, is not as comprehensive as the U.S. data.

(i) Information on total imports in the base period, $\mathrm{M}_{0 \mathrm{ij}}$ for the $\mathrm{EU}$ is available, but not the imports under different preference programs, $\mathrm{M}_{0 \mathrm{ijp}}$. Detailed EU preference utilization data were obtained from the European Union, indicating by 8-digit product and by exporting country the value of imports that were covered by a tariff preference and the value that actually entered under a preference. The exact preference scheme was not provided, only whether the applicable tariff under that preference was zero or positive. It is always assumed that trade entering under a preference always enters under the most favorable scheme. Thus $\mathrm{M}_{0 \mathrm{ijp}}$ is estimated from $\mathrm{M}_{0 \mathrm{ij}}$ using this utilization data.

(ii) The analysis assumes that the tariff reductions for sugar, bananas and rice for LDCs under the European Union's "Everything But Arms" program has already been implemented to avoid counting these changes as gains or losses in market access arising from the Doha Round. This requires a prior adjustment of import values for sugar, bananas and rice in the base period using a formula equivalent to equation (2) above in Step 4.

\section{(2) Average Preference Margin and Average Preference Margin Including Domestic Production}

The "Average Preference Margin" enjoyed by country $j$ in the U.S. (EU) is simply a weighted average difference between the tariffs paid on U.S. (EU) imports from country $j$ 
and the MFN tariff applicable to such imports, where the weights are given by country $j$ 's trade with the U.S. (EU):

$$
\frac{\sum_{i} \sum_{p}\left(\left(t_{0 i M F N}-t_{0 i j p}\right) * M_{0 i j p}\right)}{\sum_{i} \sum_{p} M_{0 i j p}}
$$

where $t_{0 i M F N}$ is the MFN tariff applicable to product $i$ and all other variables are defined in the Change in Market Access section above.

The "Average Preference Margin Including Domestic Production" enjoyed by country $j$ takes account of preferential access enjoyed by other producers and the zero tariff paid on U.S. output sold in the U.S. and EU output sold in the EU:

$$
\frac{\sum_{i} \sum_{p}\left(\left(t_{0 i_{-} A V E R A G E}-t_{0 i j p}\right) * M_{0 i j p}\right.}{\sum_{i} \sum_{p} M_{0 i j p}}
$$

where $t_{0 i_{-} A V E R A G E}$ is tariff revenue collected on U.S. (EU) imports of product $i$ divided by U.S. (EU) consumption of product $i$ :

$$
t_{0 i_{-} \text {AVERAGE }}=\frac{\sum_{j} \sum_{p}\left(t_{0 i j p} * M_{0 i j p}\right)}{C_{0 i}}
$$

\section{(2) Identifying the Elasticity of Substitution in Demand}

The estimation approach was developed in a paper by John Romalis (forthcoming, REStat). Demand elasticities are identified by examining where the US and the EU source their imports of different products before and after the implementation of the Canada-US Free Trade Agreement and the North American Free Trade Agreement (collectively referred to as NAFTA). Changes in US import sources are explained using changes in the tariff preference afforded to products of North American origin. The idea is that where North American output is afforded no new preference (where the MFN tariff rate is zero, for instance), NAFTA's only impact should come through a general equilibrium effect on output prices, or through reductions in "border effects" due to NAFTA provisions that go beyond tariff liberalization. For products where NAFTA causes a new preference to open up for North American goods, the preference should have an additional effect causing US consumers to 
substitute towards newly preferred goods and away from other sources of supply. This strategy can be derived from a simple model.

\section{Model Description}

Firms produce products under perfectly competitive conditions. Trade is driven by preference for variety and by products being differentiated by country of origin. Countries may impose ad-valorem tariffs on imports. Countries may then enter into preferential trading agreements whereby each country in the agreement lowers tariffs on imports from partner countries but need not adjust the tariff on imports from other countries. This causes consumers to substitute towards the output of preferred countries and away from all other sources of supply, including domestic production. Factor supplies are not explicitly modeled. The model assumptions are set out in detail below.

1. Products and industries are indexed by $\mathrm{i}$, countries are indexed by $\mathrm{j}$ and time by $\mathrm{t}$.

2. In each country $j$, every industry $i$ produces a product $i$ using an industry-specific factor under conditions of perfect competition with marginal $\operatorname{cost} \mathrm{c}\left(\mathrm{q}_{\mathrm{ijj}}^{\mathrm{s}}\right)$ (henceforth often denoted as $\mathrm{c}_{\mathrm{ijt}}$, where $\mathrm{q}^{\mathrm{s}}$ is industry production. Note that marginal cost depends on the quantity produced and may vary across producing country and time.

3. In every period consumers in each country are assumed to maximize Cobb-Douglas preferences over their consumption of the output of each industry, $\mathrm{Q}_{\mathrm{ijt}}$, with the fraction of income spent on industry $i$ being $b_{i j}$ (Equation (6)). Expenditure shares for each industry are therefore constant for all prices and incomes. [Note: Equations and Tables are numbered to follow those already in our paper.]

$$
U_{j t}=\sum_{i} b_{i j} \ln Q_{i j t}, \quad \sum_{i} b_{i j}=1
$$

4. The output of each industry is not a homogeneous good. Although firms in the same country produce identical goods, production is differentiated by country of origin. $\mathrm{Q}_{\mathrm{ijt}}$ can be interpreted as a sub-utility function that depends on the quantity of each variety of $i$ consumed. We choose the CES function with elasticity of substitution $\sigma>1$. Let $\mathrm{q}_{\mathrm{ijj}}{ }^{\mathrm{t}} \mathrm{denote}$ the quantity of product $i$ consumed in country $j$ that was produced in country $j^{\prime}$. $Q_{i j t}$ is defined by Equation (7):

$$
Q_{i j t}=\left(\sum_{j^{\prime}} q_{i j j^{\prime} t}^{D} \frac{\sigma-1}{\sigma}\right)^{\frac{\sigma}{\sigma-1}}
$$


5. There are transport costs for international trade. Transport costs are introduced in the convenient 'iceberg' from; $g_{i j j}$ 't units must be shipped from country $j^{\prime}$ for 1 unit to arrive in country j; $g_{\mathrm{ijj}}{ }^{\mathrm{t}}=1, \forall$.

6. Tariffs: $\tau_{\mathrm{ijj} \mathrm{t}^{-1}} 1$ is the ad-valorem tariff imposed on product $\mathrm{i}$ imported by country $\mathrm{j}$ from country $\mathrm{j}^{\prime} ; \tau_{\mathrm{ijj} \mathrm{j}^{\prime} \mathrm{t}}=1, \forall \mathrm{j}$.

\section{Equilibrium}

In equilibrium, consumers maximize utility and firms maximize profits. Because of the assumption of perfect competition, prices (exclusive of tariffs and transport costs) are equal to marginal cost, $\mathrm{c}_{\mathrm{ijt}}$. Consider the consumers in country 1 , which we will call the US. Tariffs and transport costs raise the price paid by US consumers for goods imported from country $\mathrm{j}$ to $c_{i j t} g_{i 1 j t} \tau_{i 1 j t}$. Let $Y_{1 t}$ denote US income. US consumers maximize utility subject to expenditure being equal to income in every period:

$$
\sum_{j} q_{i 1 j t}^{D} c_{i j t} g_{i 1 j t} \tau_{i 1 j t}=b_{i 1} Y_{1 t}
$$

Differentiating the Lagrangian for the consumers' constrained optimization problem with respect to consumption levels of each product, we find that tariffs on imported goods cause domestic consumers to substitute away from higher-taxed varieties. The amount of substitution depends on the level of the tariff and on the elasticity of substitution between varieties:

$$
\forall_{i}, \forall_{j}, \forall_{t}, \quad \frac{q_{i 1 j t}^{D}}{q_{i 1 j^{\prime} t}^{D}}=\left(\frac{\tau_{i 1 j^{\prime} t}}{\tau_{i 1 j t}}\right)^{\sigma}\left(\frac{c_{i j ' t}}{c_{i j t}}\right)^{\sigma}\left(\frac{g_{i 1 j^{\prime} t}}{g_{i 1 j t}}\right)^{\sigma}
$$

Equilibrium conditions for all other countries are symmetric, which will be exploited by the empirical work to control for the effect of unobserved movements in marginal cost that may be correlated with tariff movements.

\section{Results}

We use Equation (9) to derive estimating equations for demand elasticities. Equivalent equations exist for every other country, specifically, let country 2 be the aggregate of the twelve countries that were always members of the EU for the sample period 1989-1999:

$$
\forall_{i}, \forall_{j}, \forall_{t}, \quad \frac{q_{i 2 j t}^{D}}{q_{i 2 j^{\prime} t}^{D}}=\left(\frac{\tau_{i 2 j^{\prime} t}}{\tau_{i 2 j t}}\right)^{\sigma}\left(\frac{c_{i j ' t}}{c_{i j t}}\right)^{\sigma}\left(\frac{g_{i 2 j^{\prime} t}}{g_{i 2 j t}}\right)^{\sigma}
$$

Using Equations (9) and (10) we can eliminate the marginal cost terms: 


$$
\ln \frac{q_{i 1 j t}^{D}}{q_{i 1 j^{\prime} t}^{D}}-\ln \frac{q_{i 2 j t}^{D}}{q_{i 2 j^{\prime} t}^{D}}=\sigma\left(\ln \frac{\tau_{i 1 j^{\prime} t}}{\tau_{i 1 j t}}-\ln \frac{\tau_{i 2 j^{\prime} t}}{\tau_{i 2 j t}}\right)-\sigma\left(\ln \frac{g_{i 1 j^{\prime} t}}{g_{i 1 j t}}-\ln \frac{g_{i 2 j^{\prime} t}}{g_{i 2 j t}}\right)
$$

Elimination of the unobserved marginal cost terms is important because relative costs will shift following trade liberalization. Equation (11) can be transformed into an equation for Cost including Insurance and Freight (CIF) import values, to match how EU trade data are collected:

$$
\ln \frac{C_{i j t} g_{i 1 j t} q_{i 1 j t}^{D}}{C_{i j ' t} g_{i 1 j^{\prime} t} q_{i 1 j^{\prime} t}^{D}}-\ln \frac{C_{i j t} g_{i 2 j t} q_{i 2 j t}^{D}}{C_{i j ' t} g_{i 2 j^{\prime} t} q_{i 2 j^{\prime} t}^{D}}=\sigma\left(\ln \frac{\tau_{i 1 j^{\prime} t}}{\tau_{i 1 j t}}-\ln \frac{\tau_{i 2 j^{\prime} t}}{\tau_{i 2 j t}}\right)-(\sigma-1)\left(\ln \frac{g_{i 1 j^{\prime} t}}{g_{i 1 j t}}-\ln \frac{g_{i 2 j^{\prime} t}}{g_{i 2 j t}}\right)
$$

So long as we only examine countries $\mathrm{j}$ and $\mathrm{j}$ ' for which the EU does not change its relative tariffs, $\ln \frac{\tau_{i 2 j^{\prime} t}}{\tau_{i 2 j t}}$ is simply a product fixed effect. Since we do not have detailed transport cost data for EU trade, to identify $\sigma$ we assume that relative transport costs of shipping products to the US and the EU, $\ln \frac{g_{i 1 j^{\prime} t}}{g_{i 1 j t}}-\ln \frac{g_{i 2 j^{\prime} t}}{g_{i 2 j t}}$, is the sum of a product fixed effect, a year fixed effect and an error term that is orthogonal to US tariffs. This produces the basic estimating Equation (13) based on CIF import values, where $D_{i}$ and $D_{t}$ are full sets of product and year dummies respectively, while $\varepsilon_{\mathrm{ijj}}$ 't is a random disturbance term:

$$
\ln \frac{C_{i j t} g_{i 1 j t} q_{i 1 j t}^{D}}{C_{i j ' t} g_{i 1 j^{\prime} t} q_{i 1 j^{\prime} t}^{D}}-\ln \frac{C_{i j t} g_{i 2 j t} q_{i 2 j t}^{D}}{C_{i j ' t} g_{i 2 j^{\prime} t} q_{i 2 j^{\prime} t}^{D}}=D_{i}+D_{t}+\sigma \ln \frac{\tau_{i 1 j^{\prime} t}}{\tau_{i 1 j t}}+\varepsilon_{i j j^{\prime} t}
$$

Now consider country $\mathrm{j}$ to be Canada or Mexico and country $\mathrm{j}^{\prime}$ to be any other country. NAFTA's increase in the US tariff preferences for Canadian and Mexican goods, $\ln \frac{\tau_{i 1 j^{\prime} t}}{\tau_{i 1 j t}}$, will increase the share of those goods in US consumption relative to their share of EU consumption. The size of the increased share in an arbitrary industry i depends positively on the size of the increased US tariff preference, and positively on the elasticity of substitution $\sigma$ between varieties of $i$. The EU was chosen as "country 2 " for two main reasons. Firstly, its detailed trade data is available electronically. Secondly, the European Union is a relatively large trading partner for Canada and Mexico, which maximizes the number of products that can be used to estimate demand elasticities and increases the precision of the estimates. 


\section{Data}

International trade data for almost all of the world is now collected according to the Harmonized System (HS), a schedule that is standard across countries at the 6-digit level, or approximately 5,000 products. The US International Trade Commission (USITC) maintains a database at the 10-digit level (15,000 products) of US imports classified by product, country of origin, import program, month and port of arrival. Eurostat maintains a similar database for the EU.

Tariff data is based on either tariff schedules or detailed data on import duties collected. US tariff schedules for the years 1997 to the current year are available from the USITC. We extracted US tariff data for 1989 to 1996 from USITC files. US tariffs are almost invariably set at the HS 8-digit level (10,000 products). Tariffs are aggregated from the HS 8-digit level to the 6-digit level in two different ways: by taking simple averages; or by taking trade weighted averages. There are several limitations to using tariff schedules to calculate tariffs. One limitation is the effect of the maquiladoras on Mexican exports to the US. Under 'production sharing' provisions duty does not have to be paid on the US sourced content of many exports to the US, while the full value of those transactions is recorded in US trade data. The tariff schedule will therefore often overstate the NAFTA preferences. A second limitation of the tariff schedule is that preferential tariff arrangements are often circumscribed by restrictive rules of origin that need to be satisfied to qualify for the tariff preference. To partly address these limitations we also calculate tariffs using data on actual import duty paid. The drawback of this approach is that tariff rates can only be observed when there is trade. Where there is no trade, we revert to the tariff schedule for that item. This alternative set of 8-digit "applied" tariffs are also aggregated to the 6-digit level using simple averages and trade weighted averages. This gives a total of four measures of tariffs at the HS 6-digit level.

Quantitative restrictions on imports of many textile, clothing and footwear products under the Multi-Fibre Agreement (MFA) and of many agricultural products provide a further complication. Many of these restrictions are binding, although a large number are not (Carolyn Evans and James Harrigan, 2003). They are extremely difficult to account for, since many restrictions encompass many HS products and most apply bilaterally. The existence of binding quotas will tend to bias downwards the estimated substitution elasticities.

Eliminating products subject to quotas did not, however, lead to higher substitution elasticity estimates.

\section{Elasticity of Substitution Estimates}

The mean elasticity of substitution is estimated using Equation (13). We use HS 6-digit trade and tariff data from 1989-1999. Later years are omitted because the Mexico-EU free trade agreement commenced in 2000 . Country $\mathrm{j}$ is alternatively Canada or Mexico, country $\mathrm{j}^{\prime}$ is the aggregate of all countries that did not substantially change their preferential trade relations with either the US or the EU between 1989 and 1999. A list of these countries is provided in Table 13. Four different measures of tariffs are used; depending on whether the tariff 
schedule or actual duty paid are used to calculate tariffs at the 8-digit level, and on whether tariffs were aggregated to the 6-digit level using simple averages or trade weights.

Results are reported in Tables 14 and 15. Table 14 reports results based on changes in the destination of Canadian exports while Table 15 reports results based on the destination of Mexican exports. The estimates of the mean elasticity of substitution range between 6 and 11 and are reasonably precisely estimated. Moving across the columns, the estimates are slightly sensitive to the choice of tariff measure - the estimates using Canadian exports are lower when the tariff schedule is used. The estimates based on Mexican exports tend to be higher than those based on Canadian exports. The estimates are very similar whether the 'control' countries $j$ ' are limited to those listed in Table 13 or include all non-NAFTA countries. The estimates are similar in magnitude to elasticities estimated by Clausing (2001) and Lai and Trefler (2002). For the purposes of estimating the market access effects of proposed multilateral trade liberalization under the Doha Round we choose to use the more conservative substitution elasticity estimates of 6 . Note that in Table 8 we compare how sensitive these results are to choice of demand elasticity, using the higher estimates of 11 and an arbitrarily lower estimate of 3.5. 


\section{Appendix II}

Table 10. Total Exports

\begin{tabular}{|c|c|c|c|c|c|}
\hline Country/Region & $\begin{array}{l}\text { Total Exports } \\
\text { US\$ millions }\end{array}$ & $\begin{array}{c}\text { Share to U.S. } \\
\text { (percent) }\end{array}$ & $\begin{array}{c}\text { Average U.S. } \\
\text { Tariff } \\
\end{array}$ & $\begin{array}{c}\text { Share to EU-15 } \\
\text { (percent) }\end{array}$ & $\begin{array}{c}\text { Average EU } \\
\text { Tariff } \\
\end{array}$ \\
\hline \multicolumn{6}{|l|}{ African LDCs } \\
\hline Angola & $9,326.90$ & 48.31 & 0.00 & 13.79 & 0.04 \\
\hline Benin & 304.1 & 0.22 & 0.46 & 14.87 & 1.01 \\
\hline Burkina Faso & 218.6 & 0.43 & 1.45 & 23.30 & 1.59 \\
\hline Burundi & 49.3 & 13.27 & 0.00 & 50.65 & 0.11 \\
\hline Cape Verde & 23.6 & 25.22 & 1.11 & 71.75 & 0.33 \\
\hline Central African Republic & 65.7 & 0.34 & 0.05 & 91.13 & 0.07 \\
\hline Chad & 99.4 & 24.81 & 0.03 & 44.28 & 0.33 \\
\hline Comoros & 37.7 & 10.90 & 0.05 & 69.05 & 0.94 \\
\hline Congo, Dem. Rep. of & $1,026.30$ & 17.86 & 0.01 & 76.76 & 0.06 \\
\hline Djibouti & 83.2 & 0.76 & 2.87 & 6.34 & 1.23 \\
\hline Equatorial Guinea & $2,770.70$ & 34.75 & 0.01 & 36.07 & 0.02 \\
\hline Eritrea & 6.6 & 1.26 & 1.21 & 36.05 & 0.92 \\
\hline Ethiopia & 512.7 & 4.43 & 0.01 & 29.60 & 1.00 \\
\hline Gambia, The & 5.1 & 0.79 & 1.67 & 67.60 & 1.79 \\
\hline Guinea & 829.5 & 10.52 & 0.07 & 44.82 & 0.43 \\
\hline Guinea-Bissau & 76.7 & 2.76 & 0.00 & 11.57 & 0.07 \\
\hline Lesotho & 432.3 & 97.07 & 0.32 & 0.79 & 0.84 \\
\hline Liberia* & $1,049.60$ & 5.91 & 0.02 & 66.24 & 0.08 \\
\hline Madagascar & $2,454.20$ & 26.20 & 0.24 & 41.69 & 1.77 \\
\hline Malawi & 457 & 12.72 & 1.57 & 35.30 & 4.40 \\
\hline Mali & 229.4 & 1.15 & 0.40 & 28.22 & 0.28 \\
\hline Mauritania & 598.5 & 0.16 & 0.02 & 61.89 & 0.19 \\
\hline Mozambique & 985 & 0.94 & 0.59 & 77.40 & 2.89 \\
\hline Niger & 209.1 & 4.56 & 0.57 & 43.89 & 0.08 \\
\hline Rwanda & 50.4 & 0.13 & 0.00 & 8.56 & 0.13 \\
\hline Sao Tome and Principe & 6.6 & 2.90 & 2.59 & 93.93 & 0.72 \\
\hline Senegal & $1,151.20$ & 0.70 & 0.29 & 29.80 & 0.73 \\
\hline Sierra Leone & 215.1 & 3.13 & 2.53 & 81.07 & 0.47 \\
\hline Somalia & 84.4 & 0.23 & 1.91 & 2.46 & 1.02 \\
\hline Sudan & $2,480.60$ & 0.12 & 0.00 & 9.22 & 0.81 \\
\hline Tanzania & $1,218.40$ & 0.93 & 0.40 & 52.91 & 0.46 \\
\hline Togo & 494.6 & 2.11 & 0.10 & 24.34 & 0.17 \\
\hline Uganda & 164.6 & 3.09 & 0.01 & 33.53 & 1.41 \\
\hline Zambia & 727.8 & 1.77 & 0.01 & 17.98 & 8.72 \\
\hline \multicolumn{6}{|l|}{ Non-African LDCs } \\
\hline Afghanistan, Islamic Republic of & 211.3 & 29.69 & 0.10 & 11.87 & 2.00 \\
\hline Bangladesh & $5,809.40$ & 33.70 & 14.31 & 49.84 & 4.84 \\
\hline Bhutan & 58.2 & 0.90 & 0.76 & 1.78 & 1.52 \\
\hline Cambodia & $2,118.30$ & 53.28 & 15.15 & 19.94 & 4.87 \\
\hline
\end{tabular}


Table 10. Total Exports (continued)

\begin{tabular}{|c|c|c|c|c|c|}
\hline Country/Region & $\begin{array}{l}\text { Total Exports } \\
\text { US\$ millions }\end{array}$ & $\begin{array}{c}\text { Share to U.S. } \\
\text { (percent) }\end{array}$ & $\begin{array}{c}\text { Average U.S. } \\
\text { Tariff } \\
\end{array}$ & $\begin{array}{c}\text { Share to EU-15 } \\
\text { (percent) }\end{array}$ & $\begin{array}{c}\text { Average EU } \\
\text { Tariff } \\
\end{array}$ \\
\hline Haiti & 376 & 90.81 & 2.03 & 3.60 & 1.20 \\
\hline Kiribati & 27 & 7.37 & 0.03 & 1.86 & 7.47 \\
\hline Lao People's Democratic Republic* & 306.2 & 1.45 & 33.07 & 48.53 & 4.52 \\
\hline Maldives* & 113 & 32.28 & 9.00 & 15.60 & 3.69 \\
\hline Myanmar* & $2,759.60$ & 10.70 & n.a. & 15.43 & 10.07 \\
\hline Nepal & 652.7 & 29.07 & 11.33 & 9.54 & 1.94 \\
\hline Samoa & 87.1 & 13.04 & 0.36 & 5.73 & 0.67 \\
\hline Solomon Islands & 123.2 & 1.17 & 0.05 & 2.86 & 0.16 \\
\hline Timor-Leste & 6 & 2.42 & 0.00 & 42.28 & 1.08 \\
\hline Tuvalu & 2.1 & 0.36 & 0.44 & 52.51 & 5.50 \\
\hline Vanuatu & 85.8 & 1.11 & 0.00 & 4.55 & 0.17 \\
\hline Yemen, Republic of & $3,779.30$ & 1.91 & 0.08 & 2.05 & 1.51 \\
\hline \multicolumn{6}{|l|}{ Other developing countries } \\
\hline Albania & 447.1 & 0.51 & 4.03 & 93.32 & 6.43 \\
\hline Algeria* & $24,600.00$ & 19.91 & 0.12 & 59.07 & 0.15 \\
\hline Anguilla & 7.1 & 19.14 & 0.15 & 68.10 & 0.68 \\
\hline Antigua and Barbuda & 412.6 & 3.27 & 0.34 & 92.20 & 0.35 \\
\hline Argentina & $29,600.00$ & 10.60 & 1.15 & 19.70 & 8.48 \\
\hline Armenia & 670.5 & 8.20 & 2.47 & 38.90 & 1.07 \\
\hline Aruba* & 82.2 & 9.18 & 0.19 & 50.68 & 3.05 \\
\hline Azerbaijan* & $2,591.70$ & 2.46 & 0.62 & 65.65 & 0.10 \\
\hline Bahamas, The* & $1,373.30$ & 36.41 & 0.37 & 29.62 & 0.20 \\
\hline Bahrain & $6,631.60$ & 4.28 & 7.13 & 1.68 & 2.69 \\
\hline Barbados & 249.8 & 14.43 & 0.14 & 14.88 & 14.25 \\
\hline Belarus* & $9,945.60$ & 1.03 & 2.53 & 22.91 & 2.14 \\
\hline Belize & 202.8 & 56.33 & 0.59 & 28.32 & 13.02 \\
\hline Bermuda* & 465.9 & 3.34 & 0.36 & 42.03 & 0.01 \\
\hline Bolivia & $1,650.70$ & 14.29 & 0.20 & 6.74 & 0.19 \\
\hline Bosnia and Herzegovina & $1,244.90$ & 1.01 & 1.80 & 64.89 & 5.34 \\
\hline Botswana & $2,155.30$ & 0.66 & 0.02 & 85.89 & 0.06 \\
\hline Brazil & $73,100.00$ & 23.13 & 1.80 & 24.82 & 5.26 \\
\hline British Indian Ocean Ter. & 4.1 & 31.61 & 5.79 & 11.28 & 0.91 \\
\hline British Virgin Islands & 384 & 9.53 & 1.55 & 38.98 & 0.07 \\
\hline Brunei Darussalam* & $4,144.30$ & 7.75 & 10.73 & 0.33 & 3.07 \\
\hline Bulgaria & $7,540.20$ & 4.47 & 5.25 & 56.53 & 2.17 \\
\hline Cameroon & $2,245.80$ & 7.53 & 0.07 & 63.82 & 2.31 \\
\hline Cayman Islands* & 734.9 & 1.65 & 0.05 & 94.00 & 0.01 \\
\hline Chile* & $20,100.00$ & 17.78 & 0.44 & 24.32 & 2.14 \\
\hline China* & $438,000.00$ & 21.14 & 2.85 & 16.46 & 3.37 \\
\hline
\end{tabular}


Table 10. Total Exports (continued)

\begin{tabular}{|c|c|c|c|c|c|}
\hline Country/Region & $\begin{array}{r}\text { Total Exports } \\
\text { US\$ millions }\end{array}$ & $\begin{array}{c}\text { Share to U.S. } \\
\text { (percent) }\end{array}$ & $\begin{array}{c}\text { Average U.S. } \\
\text { Tariff } \\
\end{array}$ & $\begin{array}{c}\text { Share to EU-15 } \\
\text { (percent) }\end{array}$ & $\begin{array}{c}\text { Average EU } \\
\text { Tariff }\end{array}$ \\
\hline Christmas Island & 20.95 & 1.82 & 2.48 & 1.62 & 2.22 \\
\hline Cocos (Keeling) Islands & 2.2 & 12.80 & 2.42 & 3.11 & 1.63 \\
\hline Colombia & $13,100.00$ & 47.05 & 0.35 & 14.39 & 22.61 \\
\hline Congo, Rep. of & $2,708.20$ & 16.88 & 0.02 & 9.74 & 0.40 \\
\hline Cook Islands & 8.5 & 27.23 & 0.29 & 2.01 & 4.26 \\
\hline Costa Rica & $5,800.40$ & 47.12 & 0.39 & 18.24 & 24.21 \\
\hline Cote d'Ivoire & $5,493.40$ & 7.09 & 0.01 & 54.89 & 1.64 \\
\hline Croatia & $6,186.60$ & 2.65 & 0.98 & 54.99 & 0.95 \\
\hline Cuba* & $1,221.70$ & 0.03 & 0.00 & 25.88 & 3.89 \\
\hline Dominica & 39.3 & 6.32 & 0.60 & 24.92 & 0.06 \\
\hline Dominican Republic & $5,308.10$ & 85.87 & 1.14 & 7.48 & 7.98 \\
\hline Ecuador & $6,038.50$ & 40.60 & 0.24 & 17.18 & 48.77 \\
\hline Egypt & $6,160.70$ & 8.45 & 6.06 & 32.84 & 0.83 \\
\hline El Salvador & $1,254.90$ & 19.42 & 4.17 & 6.11 & 1.68 \\
\hline Falkland Island & 153.6 & 3.38 & 0.00 & 89.18 & 0.34 \\
\hline Fiji & 503 & 24.53 & 6.51 & 22.18 & 32.90 \\
\hline French Southern and Antarctic* & 8.2 & 0.84 & 1.05 & 49.23 & 5.31 \\
\hline French Polynesia* & 151.4 & 14.56 & 1.74 & 16.17 & 0.11 \\
\hline Gabon & 319.9 & 2.21 & 0.00 & 40.26 & 0.13 \\
\hline Georgia & 465.3 & 3.30 & 0.59 & 16.71 & 0.94 \\
\hline Ghana & $2,324.30$ & 2.91 & 0.06 & 54.04 & 0.27 \\
\hline Gibraltar & 173.2 & 1.67 & 1.92 & 78.01 & 2.42 \\
\hline Greenland* & 489.5 & 2.94 & 0.00 & 70.04 & 0.72 \\
\hline Grenada & 38 & 29.00 & 0.02 & 34.37 & 0.51 \\
\hline Guam & n.a. & & & & 9.45 \\
\hline Guatemala & $2,634.70$ & 30.02 & 6.74 & 5.43 & 1.33 \\
\hline Guyana & 472.1 & 19.91 & 0.07 & 33.85 & 28.24 \\
\hline Honduras & 992.3 & 41.85 & 2.35 & 17.88 & 5.34 \\
\hline India & $63,000.00$ & 18.05 & 3.36 & 21.79 & 4.46 \\
\hline Indonesia & $61,100.00$ & 12.10 & 5.48 & 13.05 & 4.04 \\
\hline Iran, Islamic Republic of* & $33,800.00$ & 0.41 & 0.62 & 14.85 & 0.35 \\
\hline Iraq & $8,942.70$ & 54.94 & 0.13 & 18.74 & 0.35 \\
\hline Jamaica & $1,631.50$ & 32.12 & 0.64 & 31.16 & 2.60 \\
\hline Jordan & $3,081.60$ & 21.51 & 0.37 & 2.90 & 1.28 \\
\hline Kazakhstan & $12,900.00$ & 0.76 & 1.54 & 15.28 & 0.66 \\
\hline Kenya & $2,551.10$ & 1.60 & 0.36 & 27.78 & 0.83 \\
\hline Korea, Dem. People's Republic of & 942.8 & 0.01 & 80.60 & 6.63 & 4.16 \\
\hline Kuwait* & $20,200.00$ & 12.28 & 0.29 & 10.17 & 0.32 \\
\hline Kyrgyz Republic & 581.7 & 1.12 & 8.91 & 3.03 & 3.93 \\
\hline Lebanon & $1,523.90$ & 4.34 & 1.12 & 9.42 & 0.96 \\
\hline Libya* & $14,600.00$ & 2.10 & 0.18 & 84.56 & 0.25 \\
\hline
\end{tabular}


Table 10. Total Exports (continued)

\begin{tabular}{|c|c|c|c|c|c|}
\hline Country/Region & $\begin{array}{r}\text { Total Exports } \\
\text { US\$ millions }\end{array}$ & $\begin{array}{l}\text { Share to U.S. } \\
\text { (percent) }\end{array}$ & $\begin{array}{c}\text { Average U.S. } \\
\text { Tariff }\end{array}$ & $\begin{array}{c}\text { Share to EU-15 } \\
\text { (percent) }\end{array}$ & $\begin{array}{c}\text { Average EU } \\
\text { Tariff }\end{array}$ \\
\hline Macao* & $2,822.68$ & 50.67 & 17.82 & 28.68 & 10.43 \\
\hline \multicolumn{6}{|l|}{ Macedonia, former Yugoslav } \\
\hline Republic of & $1,363.20$ & 5.34 & 9.45 & 54.65 & 0.84 \\
\hline Malaysia* & $105,000.00$ & 19.58 & 0.84 & 12.11 & 1.67 \\
\hline Marshall Islands* & 178.6 & 15.59 & 0.01 & 24.93 & 0.04 \\
\hline Mauritius & $1,862.10$ & 17.47 & 4.80 & 65.90 & 8.74 \\
\hline Mexico* & $165,000.00$ & 88.89 & 0.27 & 3.38 & 1.16 \\
\hline Micronesia, Federated States of* & 85.7 & 18.04 & n.a. & 0.16 & 0.48 \\
\hline Moldova & 790.3 & 4.26 & 13.81 & 23.35 & 4.69 \\
\hline Mongolia & 615.9 & 23.21 & 14.99 & 7.26 & 3.63 \\
\hline Montserrat & 1.8 & 34.30 & 3.77 & 7.90 & 1.85 \\
\hline Morocco & $8,777.20$ & 2.80 & 2.66 & 75.71 & 1.17 \\
\hline Namibia & $1,303.70$ & 2.70 & 0.21 & 29.87 & 0.56 \\
\hline Nauru* & 30.8 & 1.00 & 1.34 & 3.25 & 1.51 \\
\hline Netherlands Antilles* & $1,377.00$ & 46.92 & 0.37 & 10.09 & 7.78 \\
\hline New Caledonia* & 729 & 1.43 & 0.92 & 35.78 & 0.07 \\
\hline Nicaragua* & 605.2 & 36.50 & 7.06 & 10.71 & 0.79 \\
\hline Nigeria & $24,100.00$ & 38.26 & 0.00 & 21.84 & 0.06 \\
\hline Niue & 3.6 & 3.36 & 6.47 & 1.71 & 4.00 \\
\hline Norfolk Island & 3 & 53.92 & 0.18 & 11.03 & 0.00 \\
\hline Northern Mariana Islands* & 10.5 & n.a. & n.a. & 12.89 & 11.30 \\
\hline Oman & $11,400.00$ & 1.16 & 4.86 & 1.93 & 1.83 \\
\hline Pakistan & $12,700.00$ & 23.17 & 10.30 & 29.14 & 3.78 \\
\hline Palau* & 16.8 & 10.91 & 0.64 & 0.37 & 5.40 \\
\hline Panama & 798.7 & 52.03 & 0.14 & 23.21 & 51.25 \\
\hline Papua New Guinea & $2,260.20$ & 2.64 & 0.06 & 11.03 & 0.59 \\
\hline Paraguay & $1,241.50$ & 3.62 & 2.12 & 6.87 & 2.95 \\
\hline Peru & $8,749.40$ & 26.50 & 0.12 & 25.35 & 0.60 \\
\hline Philippines & $36,200.00$ & 20.07 & 4.05 & 16.25 & 1.41 \\
\hline Pitcairn & 3.6 & 13.55 & 0.88 & 61.00 & 0.50 \\
\hline Qatar* & $13,400.00$ & 1.68 & 3.08 & 2.09 & 0.56 \\
\hline Romania & $17,600.00$ & 3.51 & 3.21 & 67.88 & 1.01 \\
\hline Russian Federation & $134,000.00$ & 2.30 & 0.63 & 25.92 & 0.79 \\
\hline Saint Helena & 21.1 & 27.26 & 0.15 & 34.53 & 0.68 \\
\hline Saint Pierre and Miquelon* & 4.8 & 56.08 & 0.02 & 21.26 & 3.16 \\
\hline Saudi Arabia* & $89,000.00$ & 21.95 & 0.28 & 15.27 & 0.46 \\
\hline Serbia and Montenegro & $2,455.00$ & 0.64 & 1.37 & 59.62 & 10.20 \\
\hline Seychelles & 273.8 & 0.81 & 0.22 & 76.99 & 0.49 \\
\hline South Africa & $31,600.00$ & 12.15 & 0.19 & 35.57 & 1.41 \\
\hline Sri Lanka & $4,867.80$ & 36.45 & 13.39 & 29.35 & 6.46 \\
\hline
\end{tabular}


Table 10. Total Exports (continued)

\begin{tabular}{|c|c|c|c|c|c|}
\hline Country/Region & $\begin{array}{c}\text { Total Exports } \\
\text { US\$ millions }\end{array}$ & $\begin{array}{c}\text { Share to U.S. } \\
\text { (percent) }\end{array}$ & $\begin{array}{c}\text { Average U.S. } \\
\text { Tariff } \\
\end{array}$ & $\begin{array}{c}\text { Share to EU-15 } \\
\text { (percent) }\end{array}$ & $\begin{array}{c}\text { Average EU } \\
\text { Tariff }\end{array}$ \\
\hline St. Kitts and Nevis & 48.3 & 78.48 & 0.04 & 17.23 & 10.52 \\
\hline St. Lucia & 62.3 & 19.55 & 2.30 & 33.16 & 0.05 \\
\hline St. Vincent and the Grenadines & 38.1 & 13.23 & 0.16 & 30.23 & 0.09 \\
\hline Suriname & 550.6 & 26.84 & 0.01 & 36.69 & 2.57 \\
\hline Swaziland & 599 & 28.96 & 0.62 & 21.19 & 16.39 \\
\hline Syrian Arab Republic* & $5,730.70$ & 3.70 & 1.76 & 57.07 & 1.42 \\
\hline Tajikistan* & 559.3 & 1.38 & 9.28 & 18.11 & 4.09 \\
\hline Thailand & $80,300.00$ & 17.02 & 2.81 & 14.72 & 6.41 \\
\hline Tokelau & 33.6 & 20.33 & 4.40 & 35.54 & 4.41 \\
\hline Tonga & 30.6 & 49.28 & 0.04 & 4.81 & 30.19 \\
\hline Trinidad and Tobago & $5,241.30$ & 54.85 & 0.01 & 7.84 & 0.94 \\
\hline Tunisia & $7,354.40$ & 0.66 & 4.01 & 79.92 & 1.76 \\
\hline Turkey & $47,300.00$ & 7.94 & 5.17 & 51.82 & 2.02 \\
\hline Turkmenistan* & 934.1 & 8.72 & 10.11 & 29.16 & 0.64 \\
\hline Turks and Caicos Islands & 33.8 & 18.88 & 0.01 & 47.88 & 1.92 \\
\hline Ukraine* & $20,900.00$ & 1.48 & 1.48 & 19.27 & 2.86 \\
\hline United Arab Emirates* & $47,100.00$ & 2.57 & 4.09 & 8.40 & 1.44 \\
\hline Uruguay & $2,198.00$ & 11.40 & 11.77 & 22.91 & 13.62 \\
\hline Uzbekistan & $1,904.00$ & 4.60 & 3.03 & 15.77 & 0.85 \\
\hline Venezuela & $25,000.00$ & 44.35 & 0.15 & 12.56 & 1.15 \\
\hline Vietnam* & $21,800.00$ & 22.50 & 9.96 & 25.25 & 5.98 \\
\hline Wallis and Futura Islands & 1.3 & 0.70 & 4.77 & 24.45 & 2.19 \\
\hline Zimbabwe & $1,592.80$ & 3.79 & 1.83 & 33.31 & 4.44 \\
\hline \multicolumn{6}{|l|}{ Developed countries } \\
\hline Andorra & 83.3 & 0.35 & 1.06 & 88.07 & 7.43 \\
\hline Australia & $70,200.00$ & 8.76 & 1.55 & 14.21 & 2.31 \\
\hline Austria & $88,700.00$ & 5.21 & 1.58 & 58.66 & \\
\hline Belgium & $255,000.00$ & 6.71 & 1.01 & 72.57 & \\
\hline Canada & $272,000.00$ & 85.78 & 0.04 & 5.09 & 3.28 \\
\hline Cyprus & 922.9 & 1.92 & 1.42 & 56.30 & \\
\hline Czech Republic & $48,700.00$ & 2.44 & 1.49 & 69.83 & \\
\hline Denmark & $64,600.00$ & 5.71 & 0.95 & 60.60 & \\
\hline Estonia & $5,622.50$ & 2.33 & 1.28 & 58.25 & \\
\hline Faeroe Islands & 595.5 & 2.16 & 0.08 & 79.02 & 2.80 \\
\hline Finland & $52,500.00$ & 7.90 & 0.71 & 51.39 & \\
\hline France & $358,000.00$ & 6.95 & 1.12 & 62.78 & \\
\hline Germany & $749,000.00$ & 9.17 & 1.67 & 54.23 & \\
\hline Greece & $13,700.00$ & 6.42 & 2.16 & 47.32 & \\
\hline Hong Kong SAR & $229,000.00$ & 18.24 & 8.51 & 13.68 & 3.66 \\
\hline$\underline{\text { Hungary }}$ & $42,300.00$ & 3.14 & 1.04 & 73.85 & \\
\hline
\end{tabular}


Table 10. Total Exports (concluded)

\begin{tabular}{|c|c|c|c|c|c|}
\hline Country/Region & $\begin{array}{l}\text { Total Exports } \\
\text { US\$ millions }\end{array}$ & $\begin{array}{c}\text { Share to U.S. } \\
\text { (percent) }\end{array}$ & $\begin{array}{c}\text { Average U.S. } \\
\text { Tariff }\end{array}$ & $\begin{array}{c}\text { Share to EU-15 } \\
\text { (percent) }\end{array}$ & $\begin{array}{c}\text { Average EU } \\
\text { Tariff }\end{array}$ \\
\hline Iceland & $2,380.50$ & 9.45 & 0.34 & 72.07 & 1.14 \\
\hline Ireland & $93,000.00$ & 20.60 & 0.11 & 61.27 & \\
\hline Israel & $31,800.00$ & 38.04 & 0.10 & 26.50 & 1.22 \\
\hline Italy & $300,000.00$ & 8.27 & 3.23 & 54.19 & \\
\hline Japan & $472,000.00$ & 24.90 & 1.73 & 15.35 & 3.84 \\
\hline Korea, Republic of & $196,000.00$ & 19.55 & 2.24 & 14.10 & 3.48 \\
\hline Latvia & $2,893.70$ & 2.89 & 0.67 & 61.80 & \\
\hline Liechtenstein & n.a. & n.a. & 1.94 & n.a. & 0.29 \\
\hline Lithuania & $7,162.10$ & 2.80 & 1.61 & 42.06 & \\
\hline Luxembourg & $9,986.10$ & 2.42 & 1.66 & 82.44 & \\
\hline Malta & $2,467.10$ & 14.46 & 1.07 & 44.28 & \\
\hline Monaco & 362.7 & n.a. & 1.31 & 1.14 & \\
\hline Netherlands & $227,000.00$ & 5.31 & 0.93 & 72.03 & \\
\hline New Zealand & $16,500.00$ & 14.51 & 2.48 & 15.35 & 32.47 \\
\hline Norway & $67,900.00$ & 8.64 & 0.35 & 75.62 & 0.33 \\
\hline Poland & $53,500.00$ & 2.20 & 2.21 & 68.35 & \\
\hline Portugal & $31,800.00$ & 5.70 & 2.70 & 79.35 & \\
\hline San Marino & n.a. & n.a. & 1.52 & n.a. & 3.81 \\
\hline Singapore & $144,000.00$ & 14.26 & 0.47 & 13.37 & 1.99 \\
\hline Slovak Republic & $22,000.00$ & 5.26 & 2.70 & 60.67 & \\
\hline Slovenia & $12,800.00$ & 3.64 & 1.77 & 58.41 & \\
\hline Spain & $158,000.00$ & 4.10 & 2.33 & 71.10 & \\
\hline Sweden & $102,000.00$ & 11.48 & 1.00 & 53.99 & \\
\hline Switzerland & $101,000.00$ & 11.30 & 1.52 & 59.40 & 0.98 \\
\hline Taiwan Province of China & $151,000.00$ & 17.67 & 2.41 & 12.51 & 1.85 \\
\hline United Kingdom & $320,000.00$ & 15.02 & 0.96 & 53.42 & \\
\hline United States & $724,000.00$ & & & 20.84 & 2.10 \\
\hline
\end{tabular}

Note: an asterisk indicates a developing country/region that does not receive GSP from the U.S. 
Table 11. EU and U.S. Preferential Trade Arrangements

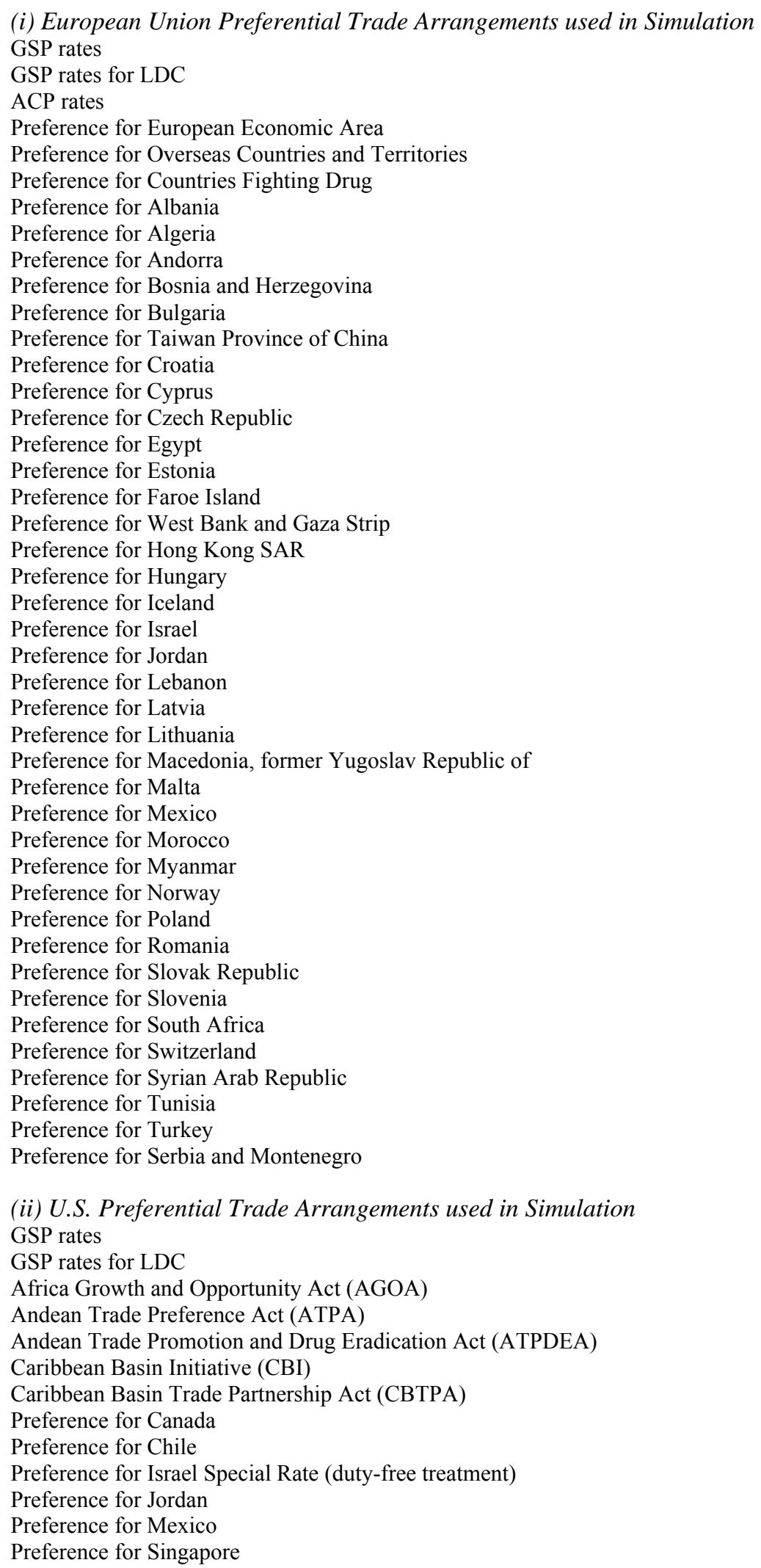

(ii) U.S. Preferential Trade Arrangements used in Simulation

GSP rates

GSP rates for LDC

Africa Growth and Opportunity Act (AGOA)

Andean Trade Preference Act (ATPA)

Andean Trade Promotion and Drug Eradication Act (ATPDEA)

Caribbean Basin Initiative (CBI)

Caribbean Basin Trade Partnership Act (CBTPA)

Preference for Canada

Preference for Chile

Preference for Israel Special Rate (duty-free treatment)

Preference for Jordan

Preference for Mexico

Preference for Singapore 
Table 12. Change in Market Access Following a 40 Percent Tariff Cut (Proxied by Change in Import Demand by European Union and United States)

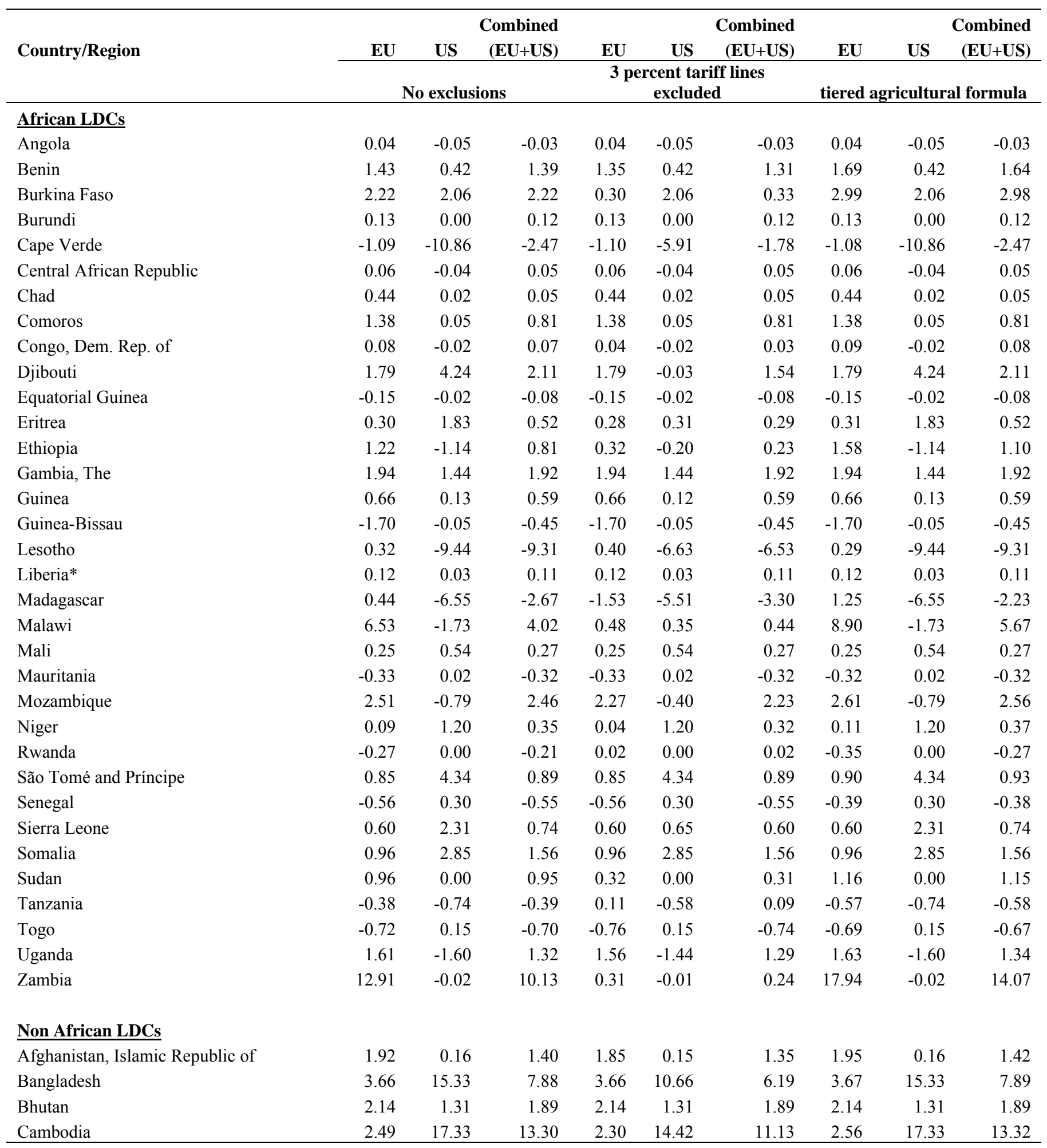


Table 12. Change in Market Access Following a 40 Percent Tariff Cut (continued) (Proxied by Change in Import Demand by European Union and United States)

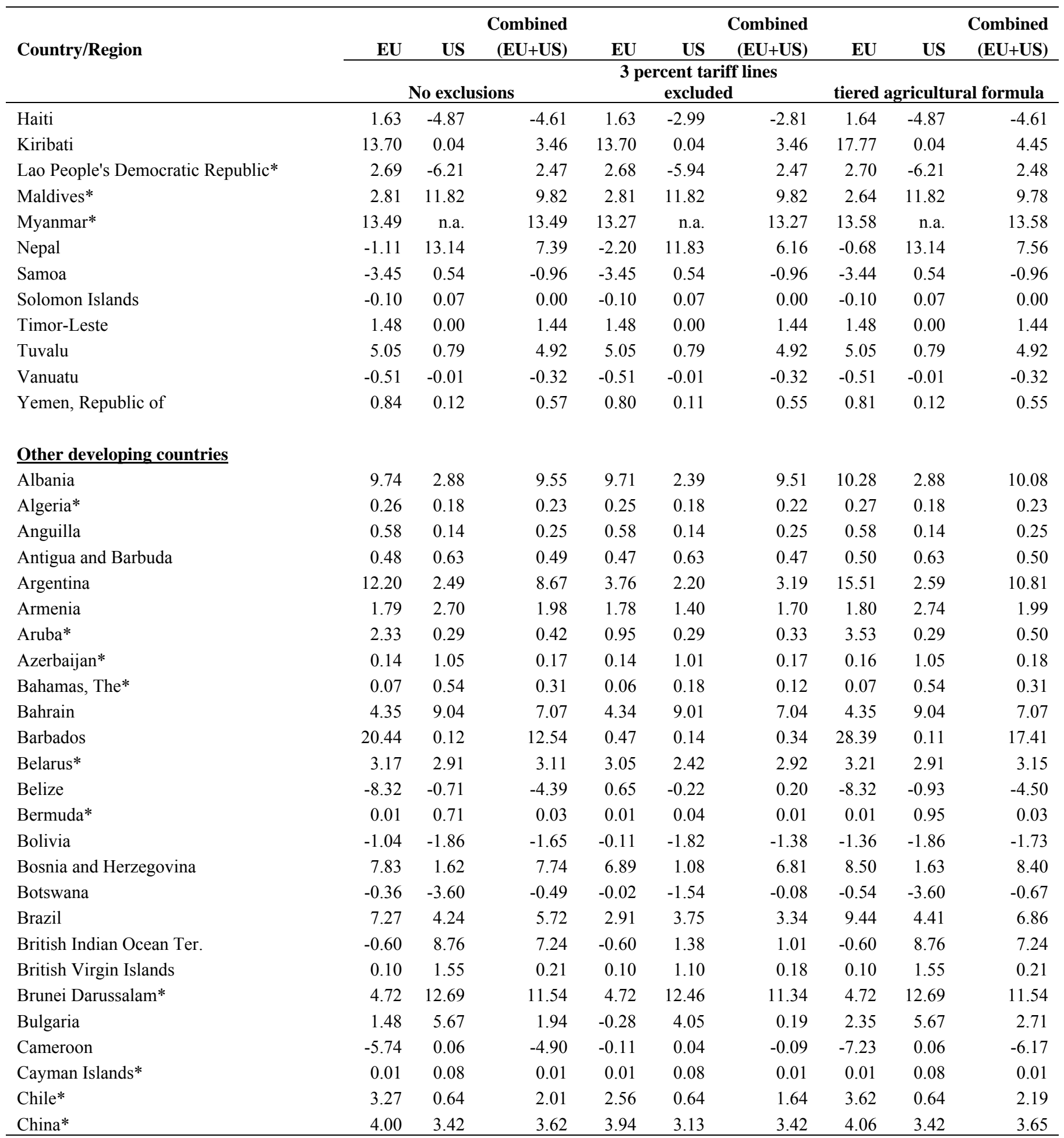


Table 12. Change in Market Access Following a 40 Percent Tariff Cut (continued) (Proxied by Change in Import Demand by European Union and United States)

\begin{tabular}{|c|c|c|c|c|c|c|c|c|c|}
\hline \multirow[t]{2}{*}{ Country/Region } & EU & US & $\begin{array}{r}\text { Combined } \\
(\mathrm{EU}+\mathrm{US}) \\
\end{array}$ & EU & US & $\begin{array}{r}\text { Combined } \\
(\mathrm{EU}+\mathrm{US}) \\
\end{array}$ & $\mathbf{E U}$ & US & $\begin{array}{r}\text { Combined } \\
(\mathrm{EU}+\mathrm{US})\end{array}$ \\
\hline & \multicolumn{9}{|c|}{3 percent tariff lines } \\
\hline Christmas Island & 3.31 & 2.00 & 2.41 & 3.31 & 1.79 & 2.27 & 3.31 & 2.00 & 2.41 \\
\hline Cocos (Keeling) Islands & 1.52 & 3.13 & 2.94 & 1.52 & 3.13 & 2.94 & 1.52 & 3.13 & 2.94 \\
\hline Colombia & 3.00 & -0.28 & 0.54 & -0.07 & -0.15 & -0.13 & 3.80 & -0.27 & 0.75 \\
\hline Congo, Rep. of & 0.54 & -0.03 & 0.14 & 0.05 & -0.03 & -0.01 & 0.74 & -0.03 & 0.20 \\
\hline Cook Islands & 1.28 & 0.47 & 0.58 & 0.85 & 0.47 & 0.53 & 1.39 & 0.47 & 0.58 \\
\hline Costa Rica & 3.72 & -0.95 & 1.15 & 0.45 & -0.77 & -0.22 & 4.59 & -0.97 & 1.54 \\
\hline Côte d'Ivoire & -2.05 & -0.01 & -1.64 & -0.06 & -0.01 & -0.05 & -2.49 & -0.01 & -2.00 \\
\hline Croatia & -0.44 & 0.69 & -0.34 & -0.90 & 0.56 & -0.76 & -0.20 & 0.70 & -0.12 \\
\hline Cuba* & 5.48 & 0.00 & 5.48 & 3.24 & 0.00 & 3.24 & 6.55 & 0.00 & 6.55 \\
\hline Dominica & -24.99 & 0.76 & -21.84 & -0.88 & 0.76 & -0.68 & -31.38 & 0.76 & -27.44 \\
\hline Dominican Republic & -5.20 & -2.87 & -3.04 & 1.16 & -1.95 & -1.71 & -6.67 & -2.86 & -3.15 \\
\hline Ecuador & 6.72 & 0.60 & 2.06 & 0.15 & 0.48 & 0.40 & 8.45 & 0.65 & 2.50 \\
\hline Egypt & 0.45 & 7.68 & 2.32 & 0.41 & 6.89 & 2.10 & 0.50 & 7.68 & 2.36 \\
\hline El Salvador & 1.67 & -0.64 & -0.48 & 1.53 & 0.15 & 0.25 & 1.72 & -0.64 & -0.47 \\
\hline Falkland Island & -2.53 & 0.00 & -2.42 & -2.66 & 0.00 & -2.53 & -2.50 & 0.00 & -2.38 \\
\hline Fiji & 49.69 & 7.51 & 24.12 & -0.01 & 7.47 & 4.52 & 69.52 & 7.51 & 31.93 \\
\hline French Southern and Antarctic* & 5.81 & 1.73 & 5.68 & 5.47 & 1.73 & 5.31 & 5.95 & 1.73 & 5.80 \\
\hline French Polynesia* & 0.09 & 3.15 & 0.54 & 0.09 & 3.15 & 0.54 & 0.09 & 3.15 & 0.54 \\
\hline Gabon & -0.01 & -0.05 & -0.04 & -0.01 & -0.05 & -0.04 & -0.01 & -0.05 & -0.04 \\
\hline Georgia & 2.16 & 0.53 & 1.83 & 2.16 & 0.53 & 1.83 & 2.22 & 0.53 & 1.88 \\
\hline Ghana & -0.24 & -0.32 & -0.25 & -0.22 & -0.32 & -0.23 & -0.28 & -0.32 & -0.29 \\
\hline Gibraltar & 3.66 & 2.96 & 3.65 & 3.66 & 0.67 & 3.64 & 3.66 & 2.96 & 3.65 \\
\hline Greenland* & -1.15 & 0.00 & -1.15 & -1.15 & 0.00 & -1.15 & -1.31 & 0.00 & -1.31 \\
\hline Grenada & -0.91 & 0.02 & -0.67 & 0.51 & 0.02 & 0.39 & -1.28 & 0.02 & -0.95 \\
\hline Guam & 12.28 & n.a. & 12.28 & 6.09 & n.a. & 6.09 & 14.41 & n.a. & 14.41 \\
\hline Guatemala & -0.18 & 4.38 & 3.98 & 0.21 & 4.28 & 3.93 & -0.33 & 4.38 & 3.97 \\
\hline Guyana & 43.12 & -0.75 & 27.24 & 1.12 & -0.14 & 0.66 & 59.72 & -0.73 & 37.84 \\
\hline Honduras & 1.87 & -2.39 & -2.04 & 1.33 & -1.21 & -1.00 & 1.98 & -2.39 & -2.03 \\
\hline India & 5.83 & 3.76 & 4.78 & 5.06 & 3.23 & 4.13 & 6.11 & 3.76 & 4.92 \\
\hline Indonesia & 5.10 & 5.90 & 5.49 & 5.10 & 3.57 & 4.34 & 5.13 & 5.90 & 5.51 \\
\hline Iran, Islamic Republic of* & 0.40 & 1.26 & 0.41 & 0.40 & 1.16 & 0.41 & 0.43 & 1.30 & 0.44 \\
\hline Iraq & 0.49 & 0.27 & 0.31 & 0.01 & 0.27 & 0.23 & 0.80 & 0.27 & 0.37 \\
\hline Jamaica & -1.87 & -5.31 & -3.01 & -0.76 & -5.04 & -2.17 & -1.99 & -5.31 & -3.08 \\
\hline Jordan & 1.57 & -9.79 & -8.01 & 1.56 & -6.77 & -5.47 & 1.66 & -9.79 & -8.00 \\
\hline Kazakhstan & 0.98 & 2.07 & 1.11 & 0.37 & 1.98 & 0.56 & 1.20 & 2.07 & 1.30 \\
\hline Kenya & 0.52 & -7.69 & -1.80 & 0.35 & -6.27 & -1.52 & 0.59 & -7.69 & -1.75 \\
\hline Korea, Dem. People's Republic of & 4.56 & 22.34 & 4.51 & 4.55 & -2.72 & 4.54 & 4.56 & -22.34 & 4.52 \\
\hline Kuwait* & 0.35 & 0.46 & 0.41 & 0.35 & 0.44 & 0.41 & 0.35 & 0.46 & 0.41 \\
\hline Kyrgyz Republic & 5.21 & 11.22 & 8.02 & 5.21 & 10.18 & 7.54 & 5.47 & 11.22 & 8.16 \\
\hline Lebanon & 0.91 & 1.31 & 1.02 & 0.72 & 1.25 & 0.86 & 0.99 & 1.31 & 1.08 \\
\hline
\end{tabular}


Table 12. Change in Market Access Following a 40 Percent Tariff Cut (continued) (Proxied by Change in Import Demand by European Union and United States)

\begin{tabular}{|c|c|c|c|c|c|c|c|c|c|}
\hline \multirow[t]{2}{*}{ Country/Region } & $\mathbf{E U}$ & US & $\begin{array}{r}\text { Combined } \\
(\mathrm{EU}+\mathrm{US}) \\
\end{array}$ & $\mathbf{E U}$ & US & $\begin{array}{r}\text { Combined } \\
(\mathrm{EU}+\mathrm{US}) \\
\end{array}$ & EU & US & $\begin{array}{r}\text { Combined } \\
(\text { EU+US) }\end{array}$ \\
\hline & \multicolumn{9}{|c|}{3 percent tariff lines } \\
\hline Libya* & 0.50 & 0.16 & 0.49 & 0.50 & 0.16 & 0.49 & 0.50 & 0.16 & 0.49 \\
\hline Macao SAR* & 14.01 & 19.31 & 17.48 & 14.01 & 11.47 & 12.34 & 14.01 & 19.31 & 17.48 \\
\hline Macedonia, former Yugoslav Republic of & -1.50 & 10.77 & -0.34 & -1.25 & 7.19 & -0.45 & -1.59 & 10.78 & -0.42 \\
\hline Malaysia* & 2.15 & 1.11 & 1.47 & 2.14 & 0.95 & 1.37 & 2.16 & 1.11 & 1.48 \\
\hline Marshall Islands* & 0.06 & 0.02 & 0.06 & 0.06 & 0.02 & 0.06 & 0.06 & 0.02 & 0.06 \\
\hline Mauritius & 11.30 & -0.71 & 9.53 & -1.26 & -0.46 & -1.14 & 16.27 & -0.69 & 13.77 \\
\hline Mexico* & 0.79 & -0.54 & -0.48 & 0.77 & -0.43 & -0.38 & 0.80 & -0.54 & -0.48 \\
\hline Micronesia, Federated States of* & 0.72 & 13.49 & 13.38 & 0.72 & 13.02 & 12.91 & 0.72 & 13.49 & 13.38 \\
\hline Moldova & 7.32 & 15.64 & 8.31 & 7.22 & 14.26 & 8.06 & 7.49 & 15.64 & 8.46 \\
\hline Mongolia & 4.33 & 16.69 & 15.52 & 4.33 & 13.43 & 12.57 & 4.33 & 16.69 & 15.52 \\
\hline Montserrat & 2.37 & 5.13 & 3.61 & -0.55 & 5.13 & 1.98 & 3.47 & 5.13 & 4.18 \\
\hline Morocco & -0.97 & 3.26 & -0.65 & -0.96 & 3.09 & -0.67 & -0.90 & 3.33 & -0.59 \\
\hline Namibia & -1.86 & -3.06 & -2.19 & -0.78 & -2.92 & -1.36 & -2.33 & -3.06 & -2.53 \\
\hline Nauru* & 1.04 & 2.23 & 1.22 & 1.04 & 2.23 & 1.22 & 1.04 & 2.23 & 1.22 \\
\hline Netherlands Antilles* & 10.36 & 0.57 & 2.67 & 0.15 & 0.49 & 0.42 & 15.60 & 0.57 & 3.79 \\
\hline New Caledonia* & 0.03 & 0.98 & 0.09 & 0.03 & 0.87 & 0.08 & 0.03 & 0.98 & 0.08 \\
\hline Nicaragua* & -0.39 & 6.87 & 6.32 & 0.19 & 7.33 & 6.80 & -0.52 & 6.87 & 6.32 \\
\hline Nigeria & 0.03 & -0.05 & -0.03 & 0.02 & -0.05 & -0.03 & 0.03 & -0.05 & -0.03 \\
\hline Niue & 4.05 & 8.52 & 8.31 & 4.05 & 8.52 & 8.31 & 4.05 & 8.52 & 8.31 \\
\hline Norfolk Island & 0.00 & 0.25 & 0.23 & 0.00 & 0.25 & 0.23 & 0.00 & 0.25 & 0.23 \\
\hline Northern Mariana Islands* & 16.19 & n.a. & 16.19 & 16.19 & n.a. & 16.19 & 16.19 & n.a. & 16.19 \\
\hline Oman & 2.02 & 6.00 & 4.53 & 2.02 & 5.33 & 4.10 & 2.06 & 6.00 & 4.54 \\
\hline Pakistan & 2.41 & 13.67 & 7.57 & 0.98 & 12.97 & 6.47 & 2.91 & 13.67 & 7.84 \\
\hline Palau* & 9.42 & 1.09 & 2.12 & 9.42 & 1.09 & 2.12 & 9.42 & 1.09 & 2.12 \\
\hline Panama & 7.09 & 0.15 & 4.50 & 0.04 & 0.08 & 0.06 & 8.95 & 0.15 & 5.67 \\
\hline Papua New Guinea & 0.08 & 0.11 & 0.09 & 0.08 & 0.11 & 0.08 & 0.22 & 0.11 & 0.21 \\
\hline Paraguay & 4.33 & 4.78 & 4.40 & 0.34 & 4.28 & 0.88 & 5.96 & 4.92 & 5.82 \\
\hline Peru & 0.34 & -1.82 & -0.95 & 0.12 & -1.73 & -0.99 & 0.41 & -1.81 & -0.91 \\
\hline Philippines & 2.03 & 4.52 & 3.42 & 2.01 & 3.39 & 2.78 & 2.18 & 4.53 & 3.49 \\
\hline Pitcairn & 0.54 & 1.28 & 0.71 & 0.54 & 1.28 & 0.71 & 0.54 & 1.28 & 0.71 \\
\hline Qatar* & 0.79 & 3.74 & 1.59 & 0.79 & 3.68 & 1.58 & 0.79 & 3.74 & 1.59 \\
\hline Romania & -0.96 & 3.28 & -0.69 & -1.71 & 2.27 & -1.46 & -0.39 & 3.28 & -0.16 \\
\hline Russian Federation & 1.20 & 0.84 & 1.13 & 0.87 & 0.73 & 0.84 & 1.33 & 0.84 & 1.23 \\
\hline Saint Helena & 0.75 & 0.23 & 0.51 & 0.75 & 0.22 & 0.50 & 0.74 & 0.23 & 0.49 \\
\hline Saint Pierre and Miquelon* & 3.69 & 0.03 & 1.85 & 3.69 & 0.03 & 1.85 & 3.69 & 0.03 & 1.85 \\
\hline Saudi Arabia* & 0.74 & 0.49 & 0.60 & 0.74 & 0.49 & 0.60 & 0.75 & 0.49 & 0.60 \\
\hline Serbia and Montenegro & 16.20 & 2.48 & 15.35 & 8.90 & 2.44 & 8.50 & 19.48 & 2.48 & 18.43 \\
\hline Seychelles & -0.96 & 0.28 & -0.93 & -0.96 & 0.28 & -0.93 & -1.19 & 0.28 & -1.16 \\
\hline South Africa & 1.86 & -0.18 & 1.31 & 1.82 & -0.17 & 1.29 & 1.90 & -0.18 & 1.34 \\
\hline Sri Lanka & 8.67 & 14.31 & 11.85 & 8.64 & 10.43 & 9.65 & 8.69 & 14.31 & 11.86 \\
\hline St. Kitts and Nevis & 8.97 & -0.64 & 2.41 & 0.16 & -0.64 & -0.39 & 12.50 & -0.64 & 3.53 \\
\hline
\end{tabular}


Table 12. Change in Market Access Following a 40 Percent Tariff Cut (continued) (Proxied by Change in Import Demand by European Union and United States)

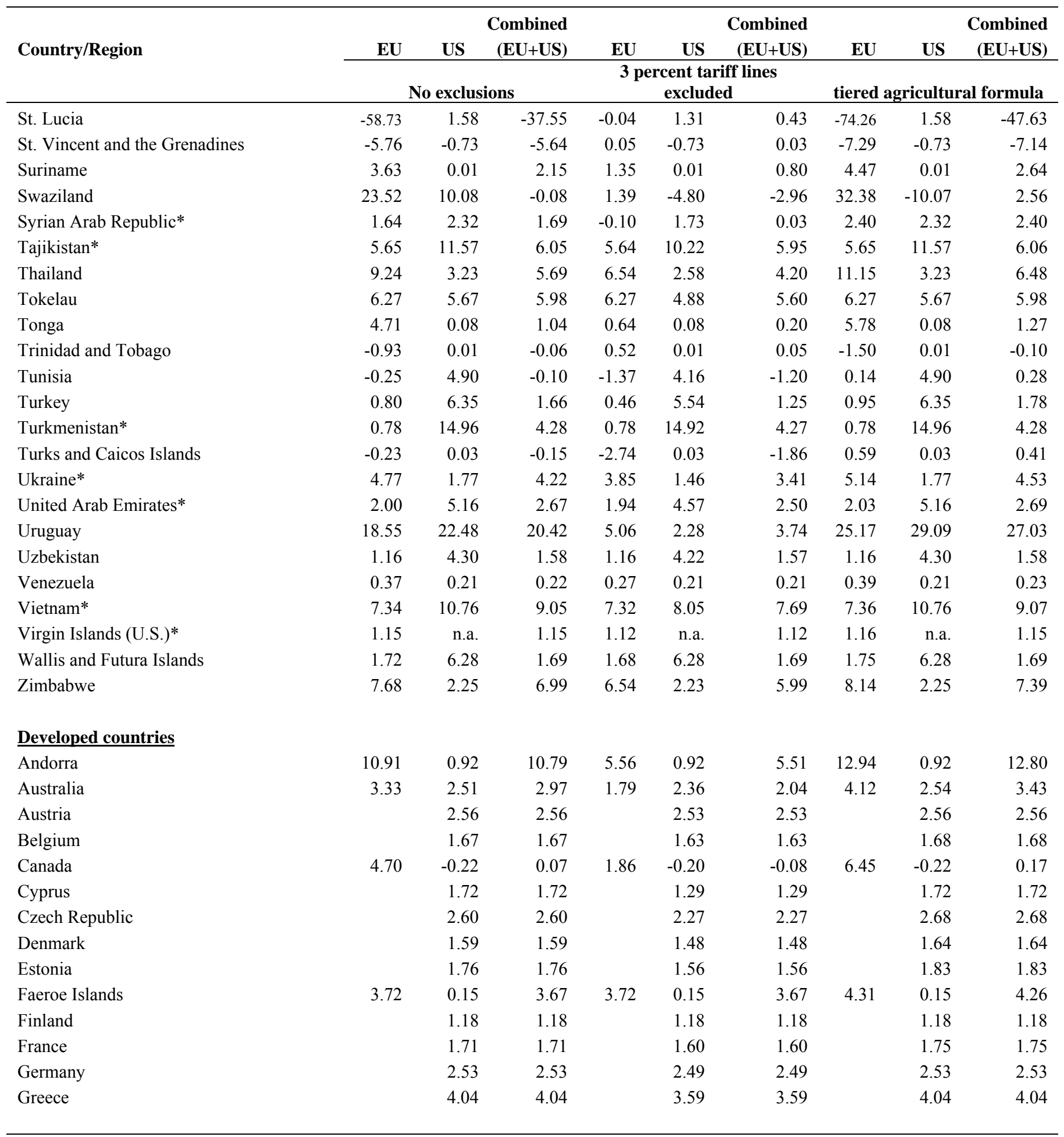


Table 12. Change in Market Access Following a 40 Percent Tariff Cut (concluded) (Proxied by Change in Import Demand by European Union and United States)

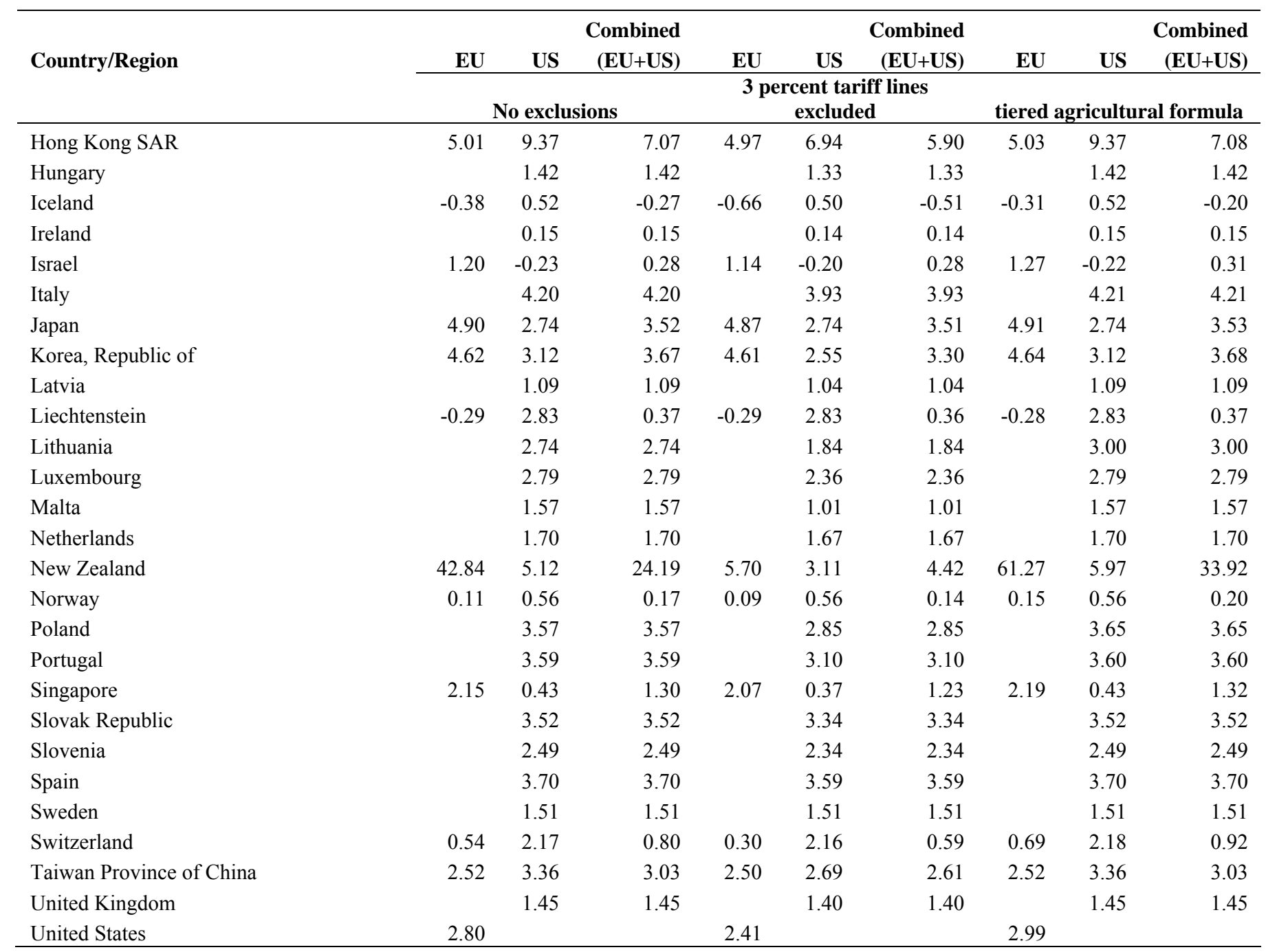

Note: an asterisk indicates a developing country/region that does not receive GSP from the U.S. 
Table 13: Countries with no substantial change in preferential trade relations with the EU

\begin{tabular}{|c|c|c|}
\hline Afghanistan & Gabon & Norfolk Island \\
\hline Angola & Gambia & North Korea \\
\hline Antigua \& Barbuda & Ghana & Norway \\
\hline Argentina & Greenland & Oman \\
\hline Aruba & Grenada & Pakistan \\
\hline Australia & Guatemala & Palau \\
\hline Bahamas & Guinea & Panama \\
\hline Bahrain & Guinea-Bissau & Papua New Guinea \\
\hline Bangladesh & Guyana & Paraguay \\
\hline Barbados & Haiti & Peru \\
\hline Belize & Honduras & Philippines \\
\hline Benin & Hong Kong & Pitcairn \\
\hline Bermuda & India & Qatar \\
\hline Bhutan & Indonesia & Rwanda \\
\hline Bolivia & Iran & Samoa \\
\hline Botswana & Jamaica & Saudi Arabia \\
\hline Brazil & Japan & Senegal \\
\hline Brunei & Kenya & Seychelles \\
\hline Burkina Faso & Kiribati & Sierra Leone \\
\hline Burundi & Korea, Republic of & Singapore \\
\hline Cambodia & Laos & Solomon Islands \\
\hline Cameroon & Lesotho & Somalia \\
\hline Cape Verde & Liberia & Sri Lanka \\
\hline Cayman Islands & Libya & St. Kitts-Nevis \\
\hline Central African Republic & Macao & St. Lucia \\
\hline Chad & Madagascar & St. Vincent \& the Grenadines \\
\hline Chile & Malawi & Sudan \\
\hline China & Malaysia & Suriname \\
\hline Christmas Island & Maldives & Swaziland \\
\hline Cocos (Keeling) Islands & Mali & Switzerland \\
\hline Colombia & Marshall Islands & Taiwan \\
\hline Comoros & Mauritania & Tanzania \\
\hline Congo, Democratic Republic of & Mauritius & Thailand \\
\hline Congo, Republic of & Mongolia & Togo \\
\hline Cook Islands & Montserrat & Tonga \\
\hline Costa Rica & Mozambique & Trinidad \& Tobago \\
\hline Cote d'Ivoire & Namibia & Tuvalu \\
\hline Cuba & Nauru & Uganda \\
\hline Djibouti & Nepal & United Arab Emirates \\
\hline Dominica & Netherlands Antilles & Uruguay \\
\hline Dominican Republic & New Caledonia & Venezuela \\
\hline Ecuador & New Zealand & Vietnam \\
\hline El Salvador & Nicaragua & Yemen \\
\hline Equatorial Guinea & Niger & Zambia \\
\hline Ethiopia & Nigeria & Zimbabwe \\
\hline Fiji & & \\
\hline
\end{tabular}


Table 14: Substitution Elasticity Estimates based on US and EU Imports from Canada and Control Countries, 1989-1999

\begin{tabular}{|c|c|c|c|c|c|c|c|c|}
\hline & $(1)$ & (2) & (3) & (4) & $(5)$ & (6) & (7) & $(8)$ \\
\hline$\sigma$ & $\begin{array}{c}6.52 \\
(0.80) \\
\end{array}$ & $\begin{array}{c}6.68 \\
(0.90) \\
\end{array}$ & $\begin{array}{c}9.38 \\
(0.88) \\
\end{array}$ & $\begin{array}{c}8.73 \\
(1.06) \\
\end{array}$ & $\begin{array}{c}6.25 \\
(0.77) \\
\end{array}$ & $\begin{array}{c}6.30 \\
(0.85) \\
\end{array}$ & $\begin{array}{r}8.49 \\
(0.84) \\
\end{array}$ & $\begin{array}{c}7.72 \\
(0.97) \\
\end{array}$ \\
\hline $\begin{array}{l}\text { Commodity } \\
\text { Fixed Effects }\end{array}$ & Yes & Yes & Yes & Yes & Yes & Yes & Yes & Yes \\
\hline $\begin{array}{l}\text { Year Fixed } \\
\text { Effects }\end{array}$ & Yes & Yes & Yes & Yes & Yes & Yes & Yes & Yes \\
\hline $\begin{array}{l}\text { Control } \\
\text { Countries }\end{array}$ & Table 13 & Table 13 & Table 13 & $\begin{array}{c}\text { Table } \\
13\end{array}$ & All & All & All & All \\
\hline $\begin{array}{l}\text { Tariff } \\
\text { Measure }\end{array}$ & $\begin{array}{c}\text { Schedule; } \\
\text { import } \\
\text { weighted }\end{array}$ & $\begin{array}{c}\text { Schedule; } \\
\text { simple } \\
\text { average }\end{array}$ & $\begin{array}{c}\text { Applied; } \\
\text { import } \\
\text { weighted }\end{array}$ & $\begin{array}{c}\text { Applied; } \\
\text { simple } \\
\text { average }\end{array}$ & $\begin{array}{c}\text { Schedule; } \\
\text { import } \\
\text { weighted }\end{array}$ & $\begin{array}{l}\text { Schedule; } \\
\text { simple } \\
\text { average }\end{array}$ & $\begin{array}{c}\text { Applied; } \\
\text { import } \\
\text { weighted }\end{array}$ & $\begin{array}{l}\text { Applied; } \\
\text { simple } \\
\text { average }\end{array}$ \\
\hline $\mathrm{N}$ & 35537 & 35533 & 35536 & 35532 & 36089 & 36085 & 36088 & 36084 \\
\hline Commodities & 4631 & 4631 & 4631 & 4631 & 4694 & 4694 & 4694 & 4694 \\
\hline
\end{tabular}

Notes: Dependent variable is $\ln$ (US imports from Canada/US imports from control countries) - $\ln ($ EU12 imports from Canada/EU12 imports from control countries) by year and HS 6-digit commodity. The substitution elasticity estimate comes from regressions of this variable on a measure of the tariff preference that the US gives to goods of Canadian origin. The EU12 includes the 12 countries that were members of the EU in 1989. The "Table 13" control countries are listed in Table 13. When "All" countries are used as a control, this includes all countries (including intra-EU international trade) with the exception of NAFTA countries. Robust standard errors adjusted for clustering on each commodity are in parentheses. There is a small difference between the number of observations in columns for the same set of control countries because a small number of observations with extreme values for the calculated tariff preference (where $\ln (1+$ preference $)$ is greater than 0.5$)$ are discarded.

Table 15: Substitution Elasticity Estimates based on US and EU Imports from Mexico and Control Countries, 1989-1999

\begin{tabular}{|c|c|c|c|c|c|c|c|c|}
\hline & (1) & (2) & (3) & (4) & (5) & (6) & (7) & (8) \\
\hline$\sigma$ & $\begin{array}{c}9.90 \\
(1.02)\end{array}$ & $\begin{array}{l}10.15 \\
(1.15)\end{array}$ & $\begin{array}{l}10.90 \\
(1.19)\end{array}$ & $\begin{array}{c}9.59 \\
(1.25)\end{array}$ & $\begin{array}{c}9.88 \\
(1.00)\end{array}$ & $\begin{array}{l}10.04 \\
(1.08)\end{array}$ & $\begin{array}{l}10.88 \\
(1.16)\end{array}$ & $\begin{array}{c}9.61 \\
(1.20)\end{array}$ \\
\hline $\begin{array}{l}\text { Commodity } \\
\text { Fixed Effects }\end{array}$ & Yes & Yes & Yes & Yes & Yes & Yes & Yes & Yes \\
\hline $\begin{array}{l}\text { Year Fixed } \\
\text { Effects }\end{array}$ & Yes & Yes & Yes & Yes & Yes & Yes & Yes & Yes \\
\hline $\begin{array}{l}\text { Control } \\
\text { Countries }\end{array}$ & Table 13 & Table 13 & Table 13 & Table 13 & All & All & All & All \\
\hline $\begin{array}{l}\text { Tariff } \\
\text { Measure }\end{array}$ & $\begin{array}{l}\text { Schedule; } \\
\text { import } \\
\text { weighted }\end{array}$ & $\begin{array}{c}\text { Schedule; } \\
\text { simple } \\
\text { average }\end{array}$ & $\begin{array}{l}\text { Applied; } \\
\text { import } \\
\text { weighted }\end{array}$ & $\begin{array}{l}\text { Applied; } \\
\text { simple } \\
\text { average }\end{array}$ & $\begin{array}{l}\text { Schedule; } \\
\text { import } \\
\text { weighted }\end{array}$ & $\begin{array}{l}\text { Schedule; } \\
\text { simple } \\
\text { average }\end{array}$ & $\begin{array}{l}\text { Applied; } \\
\text { import } \\
\text { weighted }\end{array}$ & $\begin{array}{c}\text { Applied; } \\
\text { simple } \\
\text { average }\end{array}$ \\
\hline $\mathrm{N}$ & 19335 & 19335 & 19334 & 19333 & 19414 & 19414 & 19413 & 19412 \\
\hline Commodities & 3415 & 3415 & 3415 & 3415 & 3427 & 3427 & 3427 & 3427 \\
\hline
\end{tabular}

Notes: Dependent variable is $\ln$ (US imports from Mexico/US imports from control countries) - $\ln$ (EU12 imports from Mexico/EU12 imports from control countries) by year and HS 6-digit commodity. The substitution elasticity estimate comes from regressions of this variable on a measure of the tariff preference that the US gives to goods of Mexican origin. The EU12 includes the 12 countries that were members of the EU in 1989. The "Table 13" control countries are listed in Table 13. When "All" countries are used as a control, this includes all countries (including intra-EU international trade) with the exception of NAFTA countries. Robust standard errors adjusted for clustering on each commodity are in parentheses. There is a small difference between the number of observations in columns for the same set of control countries because a small number of observations with extreme values for the calculated tariff preference (where $\ln (1+$ preference $)$ is greater than 0.5$)$ are discarded. 


\section{REFERENCES}

Alexandraki, Katerina, and Hans Peter Lankes, 2004, “The Impact of Preference Erosion on Middle-Income Developing Countries,” IMF Working Paper No. 04/169 (Washington: International Monetary Fund).

Amiti, Mary, and Jozef Konings, 2005, “Trade Liberalization, Intermediate Inputs, and Productivity: Evidence from Indonesia," IMF Working Paper No. 05/146 (Washington: International Monetary Fund).

Baldwin, R. E., and T. Murray, 1977, "MFN Tariff Reductions and Developing Country Trade Benefits Under the GSP," Economic Journal, Vol. 87, pp. 30-46.

Brenton, Paul, and Takako Ikezuki, 2004, “The Initial and Potential Impact of Preferential Access to the U.S. Market under the African Growth and Opportunity Act," World Bank Policy Research Working Paper No. 3262 (Washington: World Bank).

Clausing K. A. (2001), "Trade Creation and Trade Diversion in the Canada-United States Free Trade Agreement", Canadian Journal of Economics, 34(3), August 2001, pp.677-696.

Dean, Judith M., and John Wainio, 2005, "Quantifying the Value of U.S. Tariff Preferences," World Bank Discussion Paper, forthcoming.

Devault, James, 1996, "Competitive Need Limits and the U.S. Generalized System of Preference," Contemporary Economic Policy, Vol. 14, pp. 58-66.

European Commission, 2003a, User's Guide to the European Union's Scheme of Generalised Tariff Preferences, February 2003, available on the web at http://europa.eu.int/comm/trade/issues/global/gsp/gspguide.htm

— 2003 b, Green Paper on the Future of Rules of Origin in Preferential Trade Arrangements, Brussels (December), COM(203) 787 final.

Evans, Carolyn L. and James Harrigan (2003), "Tight Clothing: How the MFA Affects Asian Apparel Exports”, NBERWorking Paper No. 10250, January 2003.

Francois, Joseph, Bernard Hoekman, and Miriam Manchin, 2005, "Preference Erosion and Multilateral Trade Liberalization,” CEPR Discussion Paper No. 5153 (London: Center for Economic Policy Research).

Francois, Joseph, and Will Martin, 2003, "Formula Approaches for Market Access Negotiations," World Economy, Vol. 26, pp. 1-28.

Hummels, David, 2001, “Toward a Geography of Trade Costs" (unpublished; Indiana: Krannert School of Management). 
Lai, Huiwen and Daniel Trefler (2002), "The Gains from Trade with Monopolistic Competition: Specification, Estimation, and Mis-Specification", NBER Working Paper No. 9169, September 2002.

MacPhee, Craig, and David I. Rosenbaum, 1989, "The Asymmetric Effects of Reversible Tariff Changes Under the United States GSP,” Southern Economic Journal, Vol. 56, pp. 105-25.

Mattoo, Aditya, Devesh Roy, and Arvind Subramanian, 2002, "The Africa Growth and Opportunity Act and Its Rules of Origin: Generosity Undermined," IMF Working Paper No. 02/158 (Washington: International Monetary Fund).

Ozden, Caglar, and Eric Reinhardt, 2003, "The Perversity of Preferences: The Generalized System of Preferences and Developing Country Trade Policies, 19762000,” World Bank, Policy Research Working Paper Series No. 2955.

Romalis, John, 2005. "NAFTA's and CUSTFA's Impact on International Trade;” NBER Working Papers Series No. 11059 (Cambridge, Massachusetts: National Bureau of Economic Research).

Sebastian, Jean, David Laborde, and Will Martin, 2005, "Consequences of Alternative Formulas for Agricultural Tariff Cuts," Ch. 4 in (eds.) Kym Anderson and Will Martin, Agricultural Trade Reform and the Doha Development Agenda, (Washington: World Bank).

Subramanian, Arvind, 2003, "Financing of Losses from Preference Erosion," paper prepared by IMF staff for the World Trade Organization, WT/TF/COH/14/14, Geneva.

United Nations Conference on Trade and Development (UNCTAD), 2001, Improving Market Access for Least Developed Counties (unpublished; New York).

_ 2003, Trade Preferences for LDCs: An Early Assessment of Benefits and Possible Improvements, UNCTAD/ITCD/TSB/2003/8, New York and Geneva.

World Trade Organization, 2002, "Market Access: Unfinished Business Post Uruguay Round Inventory and Issues," available on the web at www.wto.org/english/res_e/booksp_e/special_study_6_e.pdf.

— 2003, "Negotiations on Agriculture: First Draft of Modalities for the Further Commitments," Geneva: World Trade Organization, TN/AG/W/1Rev.1. 19, March (The Harbinson Draft).

Yang, Yongzheng, 2005, "Africa in the Doha Round: Dealing with Preference Erosion and Beyond," IMF Policy Discussion Paper No. 05/8 (Washington: International Monetary Fund). 